\title{
Spatio-temporal variability of Air-Sea fluxes of carbon dioxide and oxygen in the Bransfield and Gerlache Straits during Austral summer 1995-96.
}

\author{
Marta Álvarez ${ }^{1}$, Aida F. Ríos ${ }^{1}$ and Gabriel Rosón ${ }^{2}$
}

1 Instituto de Investigaciones Marinas (CSIC), C/Eduardo Cabello No 6, 36208,

Vigo, Spain.

2 Dpto. Fisica Aplicada, Universidad de Vigo, Campus Lagoas-Marcosende, 36200 Vigo, Spain.

Received 1999; received in revised form 2000; accepted 2000

\begin{abstract}
The potential of the Bellingshausen Sea, Bransfield and Gerlache Straits as sinks for atmospheric $\mathrm{CO}_{2}$ was investigated by studying the carbon data obtained during FRUELA 95 (December 95-January 96) and FRUELA 96 (January-February 96) cruises. Air-sea exchange of $\mathrm{CO}_{2}$ and its relation to air-sea $\mathrm{O}_{2}$ fluxes, surface chlorophyll concentration, physical structures and other environmental variables were also studied. The processes governing the temporal evolution of total inorganic carbon between the two FRUELA cruises were assessed by means of a carbon budget.

During FRUELA 95 the frontal region associated with the Southern Boundary of the Antarctic Circumpolar Current (SbyACC) in the Bellingshausen Sea area presented high undersaturation of surface $\mathrm{CO}_{2}$ content $(<200 \mu \mathrm{atm})$, whereas strong oxygen supersaturation (AOU $<-48 \mu \mathrm{mol} . \mathrm{kg}^{-1}$ ). This was accompanied by the development of a diatom bloom. Therefore, this area acted as a strong $\mathrm{CO}_{2}$ sink and oxygen source, $-6.5 \pm 6$ and $25 \pm 29$ (mean \pm STD) $\mathrm{mmol} \mathrm{m}^{-}$ ${ }^{2} \mathrm{~d}^{-1}$, respectively. However, no phytoplanktonic biomass accumulation was reported for this area
\end{abstract}


* Corresponding author: Fax: +34 86292762

E-mail address: malvarez@iim.csic.es

in late January 96 (FRUELA 96). The mean increase of $33 \mu \mathrm{atm}$ in surface $\mathrm{pCO}_{2}$ between both surveys can be explained by seasonal warming and air-sea equilibration. On the other hand, in the Bransfield Strait area remnants of $\mathrm{CO}_{2}$-rich upwelled water caused it to act as a weak source of $\mathrm{CO}_{2}\left(1.3 \pm 1.1 \mathrm{mmol} \cdot \mathrm{m}^{-2} \cdot \mathrm{d}^{-1}\right)$ in early December 95 . From this period to late January 96 increasing phytoplanktonic activity reduced surface $\mathrm{pCO}_{2}$ by $30 \mu \mathrm{atm}$, leading to a $\mathrm{CO}_{2}$ uptake of -0.9 mmol.m $\mathrm{m}^{-2} \cdot \mathrm{d}^{-1}$. The Gerlache Strait presented a mean flux of $\mathrm{CO}_{2}$ and $\mathrm{O}_{2}$ during both FRUELA cruises of $-9.6 \mathrm{mmol} . \mathrm{m}^{-2} \cdot \mathrm{d}^{-1}$ and $19.9 \mathrm{mmol} . \mathrm{m}^{-2} \cdot \mathrm{d}^{-1}$ respectively. The carbon budget estimated for this area indicated biological processes as the main factor controlling temporal changes between both FRUELAs. Supporting this conclusion, the estimated carbon flux from the euphotic zone in this area was confirmed from measured sediment trap data.

Significant linear correlations between air-sea $\mathrm{CO}_{2}$ and $\mathrm{O}_{2}$ fluxes were noted during periods of intensive phytoplanktonic activity during FRUELA 95 and in the Gerlache Strait during FRUELA 96.

Keywords: Carbon dioxide, oxygen, air-sea fluxes, carbon budget, Antarctica. 


\section{Introduction}

High-latitude areas play an important role in the global carbon cycle due to the large oceanic area they comprise and because they are, on solubility grounds, potential sinks for dissolved gases (Jones et al., 1990; Hoppema et al., 1995).

Despite its importance to quantify the atmospheric $\mathrm{CO}_{2}$ uptake by the oceans, the role of the Southern Ocean in the global carbon cycle has not yet been elucidated. The reason is its inaccessibility due to rough weather conditions, which make surveys difficult especially during autumn and winter seasons.

There are very few data sets of surface $\mathrm{pCO}_{2}$ distributions in the Southern Ocean, but this situation has begun to change, as more surveys are being carried out in Antarctic waters (Metzl et al., 1991; Murphy et al., 1991 a, b; Takahashi et al., 1993; Poisson et al., 1994; Bellerby et al., 1995; Hoppema et al., 1995; Robertson et al., 1995; Bakker et al., 1997; Rubin et al., 1998). These studies showed that the different sectors of the Southern Ocean present contrasting behaviour. The Atlantic and Pacific sectors appear to be generally $\mathrm{CO}_{2}$-undersaturated during austral summer, while the Indian sector presents large spatial and probably temporal variation (Bakker et al., 1997).

Modelling has been another approach used for estimating the role of the Southern Ocean in the carbon cycle. Tans et al. (1990), using an atmospheric inverse model constrained by the meridional gradient of atmospheric $\mathrm{CO}_{2}$, estimated that the Southern Ocean takes 0.6 to $1.4 \mathrm{GtC} . \mathrm{yr}^{-1}$, and suggested that the annually averaged $\mathrm{CO}_{2}$ air-sea gradient is negative and small in this ocean as a whole. From spatio-temporal distributions of atmospheric $\mathrm{CO}_{2}$, Conway et al. (1994) proposed that between 19811987 the Southern Ocean behaved as a sink of 0.5 GtC.year ${ }^{-1}$, whilst on 1988-1992 period this sink increased to $1.5 \mathrm{GtC}_{\mathrm{yr}} \mathrm{r}^{-1}$, explaining the increase in the mean interhemispheric gradient. The $\mathrm{CO}_{2}$ uptake estimated by these authors is similar to that proposed by Ciais et al. (1995) (1.6 GtC.yr ${ }^{-1}$ ) from measurements of $\delta^{13} \mathrm{C}$ in atmospheric $\mathrm{CO}_{2}$.

Air-sea oxygen exchange receives scant attention, probably as a result of its global atmospheric stability (Duursma and Boisson, 1994). Additionally, few studies have undertaken the relationship between $\mathrm{CO}_{2}$ and $\mathrm{O}_{2}$ fluxes in Antarctic waters (Bouquegneau et al., 1992; Hoppema et al., 1995). 
In this study we will present data from the FRUELA 95 and 96 cruises carried out during the summer season of 1995/96 in the western basin of the Bransfield Strait, eastern part of the Bellingshausen Sea and the Gerlache Strait, with the aims of: i) evaluating the spatio-temporal differences between both cruises; ii) estimating the $\mathrm{CO}_{2}$ and $\mathrm{O}_{2}$ air-sea exchange and their relationship and iii) accomplishing a carbon budget as a tool for assessing the factors controlling total inorganic carbon changes in the mixed layer.

\section{Material and Methods}

Two surveys on board the R/V "Hespérides" were conducted on the Gerlache and Bransfield Straits areas from December 1995 to February 1996 as part of the Spanish contribution to JGOFS in the Southern Ocean.

A detailed description of the survey strategy is given by Estrada and Anadón (this issue). Briefly, during both FRUELA 95 and 96 cruises a macroscale grid survey was conducted in the Bellingshausen Sea and western basin of the Bransfield Strait (Figure 1a). The first macroscale survey (Macro'95) was performed between 3 and 9 December 1995, and the second (Macro'96) from 21 to 27 January 1996. Additionally, a mesoscale sampling (Meso'95) was carried out in the western basin of Bransfield Strait during the FRUELA 95 cruise (Figure 1b). Moreover, during both FRUELA 95 and 96 a section along the Gerlache Strait was sampled (Figure 1c).

Continuous profiles of salinity, temperature and pressure were recorded with a EG\&G CTD probe. Salinity and density were calculated using the equations of UNESCO (1984). Water samples for nutrients, dissolved oxygen, $\mathrm{pH}$ and alkalinity were taken at selected levels. Samples for chlorophyll $a$ were taken from surface to 100 meters depth.

Dissolved oxygen was determined by Winkler potentiometric titration, with an estimated error of $\pm 1 \mu$ mol. $\mathrm{kg}^{-1}$. Apparent Oxygen Utilisation (AOU) was calculated using oxygen saturation following the Benson and Krause equation (UNESCO, 1986). Chlorophyll $a(\mathrm{Chl} a)$ concentration was determined fluorometrically after extraction with 90\% acetone overnight, using a 10,000 R Turner fluorometer according to Yentsch and Menzel (1963). The precision of this method is $\pm 0.05 \mathrm{mg} \cdot \mathrm{m}^{-3}$. 
A Metrohm E-654 pH-meter equipped with a Ross (Orion 81-04) combined glass electrode was used to determine $\mathrm{pH}$ on the NBS scale. The temperature was measured using a platinum resistance thermometer and finally $\mathrm{pH}$ was referred to a standard temperature of $15^{\circ} \mathrm{C}\left(\mathrm{pH}_{15}\right)$ according to Pérez and Fraga (1987a). The method has a shipboard precision of $\pm 0.002 \mathrm{pH}_{15}$ (Ríos and Rosón, 1996) and an accuracy of \pm 0.004 $\mathrm{pH}_{15}$ using samples of Certified Reference Material (CRMs) provided by Dr. Dickson from the Scripps Institution of Oceanography (Ríos and Pérez, 1999; Ríos and Rellán, 1998).

Alkalinity was determined by automatic potentiometric titration with $\mathrm{HCl}$ at a final pH of 4.44 (Pérez and Fraga, 1987b). The electrodes were standardised using an NBS buffer of pH 7.413 and checked using an NBS buffer of 4.008. This method has a precision of $0.1 \%$ (Pérez and Fraga, 1987b), and an accuracy of $\pm 1.4 \mu \mathrm{mol} . \mathrm{kg}^{-1}$ (Ríos and Pérez, 1999; Ríos and Rellán, 1998). Total inorganic carbon (TIC) and partial pressure of $\mathrm{CO}_{2}\left(\mathrm{pCO}_{2}\right)$ were estimated from $\mathrm{pH}_{15}$ and alkalinity data using the thermodynamic equations of the carbonate system (Dickson, 1981) and the constants determined by Mehrbach et al. (1973) and Weiss (1974) with an accuracy of $\pm 4 \mu \mathrm{mol} . \mathrm{kg}^{-1}$ and $\pm 5 \mu \mathrm{atm}$, respectively (Millero, 1995, Lee et al., 1997). We used Mehrbach's constants rather than more recent constants (Roy et al., 1993) since the temperature effect on $\mathrm{pCO}_{2}$ obtained using Merhbach's constants is more consistent with the experimental values (Takahashi et al., 1993, Millero et al, 1994, Lee et al., 1997). This procedure was verified by Ríos and Rosón (1996).

The air-sea $\mathrm{CO}_{2}$ exchange (mmolC.m $\mathrm{m}^{-2} \cdot \mathrm{d}^{-1}$ ) was calculated using the following equation:

$$
\mathrm{FCO}_{2}=0.24 \cdot \mathrm{k} \cdot \mathrm{S} \cdot \rho \cdot 10^{-3} \cdot\left(\mathrm{pCO}_{2} \mathrm{Oc}-\mathrm{pCO}_{2} \text { at }\right)
$$

where $\mathrm{k}$ is the exchange coefficient $\left(\mathrm{cm} \cdot \mathrm{h}^{-1}\right), \mathrm{S}$ is $\mathrm{CO}_{2}$ seawater solubility $\left(\mathrm{mol} \cdot \mathrm{kg}^{-1} \cdot \mathrm{atm}^{-1}\right)$, pCO $\mathrm{O}_{2} \mathrm{Oc}$ is surface ocean $\mathrm{CO}_{2}$ partial pressure, $\mathrm{pCO}_{2}$ at is atmospheric $\mathrm{CO}_{2}$ partial pressure (both in $\mu \mathrm{atm}$ ) and 0.24 is a unit conversion factor. Seawater $\mathrm{CO}_{2}$ solubility is calculated from Weiss (1974). $\rho$ is seawater density in $\mathrm{kg} \cdot \mathrm{m}^{-3}$.

Seasonal and inter-annual variations in atmospheric $\mathrm{CO}_{2}$ are small compared to $\mathrm{pCO}_{2}$ variations in the surface ocean (Andrié et al., 1986). In addition, on the Southern hemisphere the seasonal amplitude of atmospheric $\mathrm{CO}_{2}$ partial pressure $\left(\mathrm{pCO}_{2}\right.$ at $)$ is much smaller than in the northern hemisphere and their phases are opposite (Conway et al., 1994). We have therefore assumed a constant value of $\mathrm{pCO}_{2}$ at equal to $358.5 \mu$ atm for 
FRUELA 95 and 96 cruises. This value was estimated from $\mathrm{CO}_{2}$ mixing ratios taken at the Palmer station $\left(64^{\circ} 55^{\prime} \mathrm{S}, 64^{\circ} 00^{\prime} \mathrm{W}\right)$ reported by the NOAA, Climate Monitoring and Diagnostics Laboratory (CMDL), Carbon Cycle group during the sampling period.

The impact of wind speed on the exchange coefficient, k, was calculated using the equations given by Liss and Merlivat (1986) modified by Woolf and Thorpe (1991):

$\begin{array}{ll}\mathrm{k}=0.17 \cdot \mathrm{U}_{10} \cdot(660 / \mathrm{Sc})^{2 / 3} & \mathrm{U}_{10}<\mathrm{U}_{1} \text { : smooth water regime } \\ \mathrm{k}=\left(2.85 \cdot \mathrm{U}_{10}-9.65\right) \cdot(660 / \mathrm{Sc})^{1 / 2} & \mathrm{U}_{10}>\mathrm{U}_{1} \text { : rough water regime } \\ \mathrm{U}_{1}=9.65 \cdot\left[2.85-0.17 \cdot(660 / \mathrm{Sc})^{1 / 6}\right]^{-1} & \end{array}$

where $\mathrm{Sc}$ is the Schmidt number defined below, and $\mathrm{U}_{10}$ is the wind speed $10 \mathrm{~m}$ above the ocean surface $\left(\mathrm{m}_{\mathrm{s}} \mathrm{s}^{-1}\right)$. The Schmidt number is calculated from its relation with temperature (Jähne et al., 1987; Wanninkhof, 1992):

$$
\mathrm{Sc}=2073.1-125.62 \cdot \mathrm{T}+3.6276 \cdot \mathrm{T}^{2}-0.043219 \cdot \mathrm{T}^{3}
$$

where $\mathrm{Sc}$ is the Schmidt number and $\mathrm{T}$ is temperature $\left({ }^{\circ} \mathrm{C}\right)$.

Meteorological parameters (air temperature, atmospheric moisture content, atmospheric pressure at sea level, wind speed at $10 \mathrm{~m}$ above sea level and wind direction) were taken from the shipboard online data-acquisition system, which produced 5 minutes averages.

One of the major uncertainties in the assessment of air-sea gas exchange is the parameterization of the dependence of the exchange coefficient on wind speed (Wanninkhof, 1992; Lundberg, 1994, Bakker, et al., 1997). The Liss-Merlivat relationship used in this study, is based on gas transfer velocities measured over 1-2 days on a small lake. If used this relationship with long-term averaged winds, low gas transfer values are obtained (Wanninkhof, 1992). Thus, ten minutes averages around the station time were used for the Woolf and Thorpe (1991) gas exchange coefficient. Considering an error of $\pm 1 \mathrm{~m} . \mathrm{s}^{-1}$ in the wind speed, of $\pm 4 \mu \mathrm{atm}$ in $\mathrm{pCO}_{2} \mathrm{oc}$ and $\pm 1 \mu$ atm in $\mathrm{pCO}_{2}$ at, the maximum absolute error in $\mathrm{FCO}_{2}$ is $\pm 1.5 \mathrm{mmolC} . \mathrm{m}^{-2} . \mathrm{d}^{-1}$, this is a relative error to its mean value of $\pm 32 \%$.

Oxygen fluxes $\left(\mathrm{mmolO}_{2} \cdot \mathrm{m}^{-2} \cdot \mathrm{d}^{-1}\right)$ were calculated using the following equation:

$$
\mathrm{F} \mathrm{O}_{2}=-0.864 \cdot \mathrm{k}_{\mathrm{O} 2} \cdot \rho \cdot 10^{-3} \cdot 10^{-3} \cdot \mathrm{AOU}
$$


where $\mathrm{k}\left(10^{3} \cdot \mathrm{cm} \cdot \mathrm{s}^{-1}\right)$ is the piston velocity for oxygen, AOU is the apparent oxygen utilisation defined previously $\left(\mu \mathrm{mol} . \mathrm{kg}^{-1}\right.$ ) and 0.864 is an unit conversion factor. The relationship between $\mathrm{k}_{\mathrm{O} 2}$ and wind speed has been studied by Kester (1975) and parameterized by Rosón (1992). $\rho$ is seawater density in $\mathrm{kg} \cdot \mathrm{m}^{-3}$. The estimated relative maximum error of $\mathrm{F}_{2}$ is about $\pm 35 \%$.

Positive values of $\mathrm{FCO}_{2}$ and $\mathrm{FO}_{2}$ indicate effluxes of both gasses to the atmosphere, negative values indicate input from the atmosphere to the ocean.

\section{Results}

Surface distributions.

Hydrography overview.

The surveyed area is characterised by two main hydrographic features: the Southern boundary of the Antarctic Circumpolar Current (SbyACC) is a circumpolar structure, separating the Antarctic Circumpolar Current waters from an area of relatively vertical homogeneity extending on the South Shetlands continental shelf and the Bransfield current (BC) in the western basin of the Bransfield strait (Figure 1a, Figure 3a from García et al., this issue).

More detailed, hydrographic and dynamic conditions in Bransfield Strait are marked by the presence of a NE-SW thermal frontal area, the Bransfield Front (Gomis et al., this issue; García et al., this issue) (Figure 1b). This front separates Transitional Zonal Water with Bellingshausen influence (TBW) in the Northwest from Transitional Zonal Water with Weddell Sea influence (TWW) in the Southeast (García et al., this issue).

\section{FRUELA 95}

In the western basin of the Bransfield Strait, surface salinity and temperature reflected a cold $\left(-0.6\right.$ to $\left.-0.3{ }^{\circ} \mathrm{C}\right)$ and relatively salty (33.95-34.13) water mass with a Weddell Sea influence (García et al., this issue). Whereas in the South-west area a warmer $\left(-0.7\right.$ to $\left.0.14{ }^{\circ} \mathrm{C}\right)$ and fresher (33.7-33.8) water mass with a Bellingshausen Sea origin contrasted to the warm water $\left(0\right.$ to $\left.0.5^{\circ} \mathrm{C}\right)$ coming from the Drake passage (García et al., this issue) (Figure 2a).

Surface distributions of $\mathrm{Chl} a, \mathrm{AOU}$ and $\mathrm{pCO}_{2}$ (Figure $2 \mathrm{~b}-\mathrm{d}$ ) were marked by a SW-NE frontal zone, which was related to the SbyACC. Associated with this front an 
area of high photosynthetic activity on the North-eastern part of the Bellingshausen Sea (Belling.) domain (see Figure 1a for domains) can be discerned from surface distributions of these variables. The phytoplankton activity in this area was denoted not only by a strong maximum in chlorophyll $\left(4 \mathrm{mg} \cdot \mathrm{m}^{-3}\right)$ but also by minima of $\mathrm{pCO}_{2}(194$ $\mu \mathrm{atm}$ ), and AOU (-48 $\mu \mathrm{mol} . \mathrm{kg}^{-1}$ ) (station 15, figure 3b-d). Moreover, Castro et al. (this issue) described the highest rates of nutrient utilisation in this area. Surface mean characteristics in the Belling. domain during FRUELA 95 can be seen in table 1.

The Bransfield Strait (Bransf.) domain during the 1995 survey presented the lowest mean surface temperature $\left(-0.5^{\circ} \mathrm{C}\right)$ (see Figure $2 \mathrm{a}$ and table 1), Chl $a$ concentrations ranged from 1 to $2 \mathrm{mg} \cdot \mathrm{m}^{-3}$ and AOU values were undersaturated (12 $\mu$ mol. $\mathrm{kg}^{-1}$ ) as a mean (Figure $2 \mathrm{~b}$ and $\mathrm{c}$, table 1 ). But the most notable feature was the positive values of $\Delta \mathrm{pCO}_{2}$ (Figure $2 \mathrm{~d}$ and table 1), revealing that it acted as a weak source of $\mathrm{CO}_{2}$ to the atmosphere in contrast with the Belling. domain, as we will see later on.

As suggested by the corresponding surface distributions, there existed a high correlation (model II, Sockal and Rolhf, 1995) between surface AOU and $\mathrm{pCO}_{2}$ :

$$
\mathrm{pCO}_{2}( \pm 25)=328( \pm 7)+2.3( \pm 0.3) \cdot \mathrm{AOU}, \mathrm{r}^{2}=0.82, \mathrm{p}<0.0001
$$

This relationship shows that once oxygen is equilibrated, $\mathrm{pCO}_{2}$ is still undersaturated with respect to the atmospheric value. This fact can be related to the slower equilibration timescale for carbon dioxide (Broecker and Peng, 1982).

No significant correlation was found between $\mathrm{pCO}_{2}$ and $\mathrm{Chl} a$ concentration. However, two groups of stations can be discerned according to the relationship between $\mathrm{pCO}_{2}$ and chlorophyll: those with a surface $\mathrm{pCO}_{2}$ highly undersaturated ( $\left.<270 \mu \mathrm{atm}\right)$ corresponded to Chl $a$ values higher than $2.5 \mathrm{mg} . \mathrm{m}^{-3}$, and those with lower chlorophyll concentrations $\left(<2 \mathrm{mg} \cdot \mathrm{m}^{-3}\right)$ associated with a wider range of surface $\mathrm{pCO}_{2}$ levels (370$270 \mu \mathrm{atm})$, but clearly less undersaturated than the previous group. Thus, $\mathrm{CO}_{2}$ uptake by photosynthetic organisms is supposed to control surface $\mathrm{CO}_{2}$ distribution during Macro'95.

Concerning the air-sea exchange of $\mathrm{CO}_{2}$ during Macro' 95 (Figure 2f), only the western basin of the Bransfield Strait behaved as a weak source of carbon dioxide to the atmosphere, with a mean value of $1.2 \mathrm{mmolC} \cdot \mathrm{m}^{-2} \cdot \mathrm{d}^{-1}$ (Table 1$)$. Whereas the maximum influx of $\mathrm{CO}_{2}$ was located in the Belling. domain, reaching values as low as -20 
mmolC. $\mathrm{m}^{-2} \cdot \mathrm{d}^{-1}$. These maxima influxes did not coincide which the maxima $\mathrm{pCO}_{2}$ gradient associated to the SbyACC, due to lower wind velocities recorded in this area.

The distribution of the air-sea oxygen exchange during Macro'95 (Figure 2e) resembled that of $\mathrm{CO}_{2}$ but in opposite direction:

$$
\mathrm{FCO}_{2}( \pm 3.6)=-2.2( \pm 0.9) \quad-0.18 \quad( \pm 0.03) \cdot \mathrm{FO}_{2}, \quad \mathrm{r}^{2}=0.69, \quad \mathrm{p}<0.0001 .
$$

According to this equation and supporting equation (5) there should be a residual carbon flux towards the ocean although oxygen is already equilibrated.

As commented previously, a more detailed survey was carried out in the western part of the Bransfield Strait during FRUELA 95 (Meso' 95, figure 1b). Here, the Bransfield front can be discerned by hydrographic and nutrients distributions, and by surface $\mathrm{pCO}_{2}$ (Figure 3d). In a NE-SW orientation an area with a $\mathrm{CO}_{2}$ content around $345 \mu$ atm separated TBW in the Northwest from TWW in the Southeast with higher $\mathrm{pCO}_{2}$ values. In contrast, neither the surface distribution of chlorophyll nor AOU presented a clear relation to hydrographic structures. However, a North-eastward increase in the cumulative photosynthetic activity can be assessed from the surface distribution of AOU (Figure 3c). Surface Chl $a$ concentration (Figure 3b) ranged from 0.8 to $4.4 \mathrm{mg} \cdot \mathrm{m}^{-3}$, with the highest values in the TWW area.

Neither $\mathrm{Chl} a$ nor AOU presented a significant correlation with $\mathrm{pCO}_{2}$. Nevertheless in the North-eastern part of the surveyed area undersaturated values of $\mathrm{CO}_{2}$ were associated to supersaturation of oxygen and to relatively high values of $\mathrm{Chl} a$ and, on the other hand, the maximum in surface $\mathrm{pCO}_{2}$ content near Trinity I. coincided with the maximum AOU concentration (Figure $3 \mathrm{c}$ and $\mathrm{d}$ ). Therefore, in this local area $\mathrm{CO}_{2}$ effluxes were recorded and associated with maximum influxes of oxygen (Figure $3 \mathrm{e}$ and f).

\section{FRUELA 96}

Dynamic features remained practically the same during both Macro'95 and 96 (Gomis et al., this issue). However, hydrographic variables showed the influence of seasonal warming, the greatest rise in the mean surface temperature was recorded in the Belling. domain $\left(1.91{ }^{\circ} \mathrm{C}\right.$, table 2). In general, surface $\mathrm{pCO}_{2}$, AOU and $\mathrm{Chl} a$ ranges during macroscale 96 were reduced to about a half with respect to conditions during macroscale 95. 
The highest concentrations of surface Chl $a$ were reported during Macro'96 in the Bransfield Strait (Figure 4b). Although the range of surface oxygen variation was reduced from early December $95\left(330-400 \mu \mathrm{mol} . \mathrm{kg}^{-1}\right)$ to late January 96 (326-350 $\mu$ mol. $\mathrm{kg}^{-1}$ ), surface AOU (Figure 4c) presented a wider range of values (from -6 to 10 $\mu$ mol. $\mathrm{kg}^{-1}$ ) during Macro'96 due to the greater surface temperature gradient. Warm water of the Belling. domain was slightly supersaturated as a mean (AOU $=1 \mu$ mol. $\mathrm{kg}^{-1}$, table 1), while the highest undersaturations were recorded in the colder Bransfield Strait. This high undersaturation coincided with local $\mathrm{CO}_{2}$ surface values well above atmospheric levels (Figure 4d). Conversely, the lowest surface $\mathrm{pCO}_{2}$ was recorded, as during Macro'95, in the Belling. domain.

On the other hand, no significant correlation was found between either AOU or Chl $a$ and $\mathrm{pCO}_{2}$ on surface waters during this period. These evidences suggest that physical factors as well as biological activity influenced surface $\mathrm{pCO}_{2}$ distribution during Macro'96.

During late January 96, only the area near Livingston island in the Bransf. domain behaved as a source of $\mathrm{CO}_{2}\left(1.6 \mathrm{mmolC} \cdot \mathrm{m}^{-2} \cdot \mathrm{d}^{-1}\right.$, figure $\left.4 \mathrm{f}\right)$. However, considering the whole domain it was practically in atmospheric equilibrium (Table 1). The mean influx calculated for the Belling. domain was $-4 \mathrm{mmolC} \cdot \mathrm{m}^{-2} \cdot \mathrm{d}^{-1}$, only $2 \mathrm{mmolC} \cdot \mathrm{m}^{-2} \cdot \mathrm{d}^{-1}$ lower than during early December 95.

Surface variability of oxygen fluxes during FRUELA 96 did not reflect that of $\mathrm{CO}_{2}$ fluxes. The oxygen flux distribution was modulated by $\mathrm{AOU}$, which was in turn, mainly controlled by temperature. Fluxes of oxygen towards the atmosphere were obtained for cold surface waters in the Bransfield Strait (Figure 4e). In comparison to Macro'95 oxygen fluxes during Macro'96 were 10 fold lower.

\section{Gerlache Strait sections during FRUELA 95 and 96}

Temperature distribution in the upper $100 \mathrm{~m}$ of the southwestern part of the Gerlache Strait sampled area (Figure 5a and e) was characterised by a minimum around 50m, belonging to the AASW (Antarctic Surface Water) (García et al., this issue). This minimum disappeared in the stations located near the Scholaert Strait during both FRUELA cruises, resulting in a nearly homogeneous vertical profile of temperature in the Gerlache central area (Station 40 in figure 5a and 193 in figure 5e). This fact can be attributed to an intrusion of water from the Bellingshausen Sea across the Scholaert 
Strait (García et al., this issue). In contrast, the upper water column in the SW and NE areas was highly stratified during FRUELA 95, the great thermal gradient, as well as a high near-surface salinity gradient (not shown) can be related to ice-melting. During early December 95, the SW and NE areas presented high surface concentrations of Chl $a$ $\left(>3 \mathrm{mg} \cdot \mathrm{m}^{-3}\right.$ ) (Figure $5 \mathrm{~d}$ ) especially the NE one with a maximum of $7 \mathrm{mg} \cdot \mathrm{m}^{-3}$. These biomass accumulations were associated with shallow mixed layer depths $(6-17 \mathrm{~m})$ and high stratification (Castro et al., this issue). A subsurface maximum of Chl $a$ (4 mg.m $\mathrm{m}^{-3}$ ) related to a v-shaped distribution of $\mathrm{AOU}$ and $\mathrm{pCO}_{2}$ was discerned in the central area of the Gerlache Strait (Figure $5 \mathrm{~b}$ and $\mathrm{c}$ ), in agreement with the local downwelling suggested by temperature and the deepening of the UML (35m) (Castro et al., this issue).

Surface accumulations of phytoplankton biomass on both sides of the Gerlache Strait were related to high dissolved oxygen contents (>330 $\left.\mu \mathrm{mol} \cdot \mathrm{kg}^{-1}\right)$ (not shown), but only surface waters on the NE area presented slight oversaturations of oxygen (Figure 5c), whereas the SW area was significantly undersaturated, likely due to lower temperature values. Surface water $\mathrm{CO}_{2}$ contents (Figure 5b) were lower than atmospheric ranging from 288 to $340 \mu \mathrm{atm}$, with a minimum of $270 \mu \mathrm{atm}$ in the $\mathrm{SW}$ area. Below $50 \mathrm{~m} \mathrm{pCO} 2$ was $457 \pm 23 \mu \mathrm{atm}$.

No correlation was found between surface-water $\mathrm{pCO}_{2}$ and either AOU or Chl $a$.

Upper level hydrographic conditions in the Gerlache Strait during early January 96 showed the influence of seasonal warming, as water temperature increased by about 0.6 ${ }^{\circ} \mathrm{C}$ (Figure 5e) and salinity (not shown) decreased by about 0.3 from conditions during December 95.

The vertical distribution of Chl $a$ concentration in January 96 (Figure 5h) presented a similar pattern to that of December 95. The highest concentrations were noted in the SW and central areas, where surface stratification was higher (Castro et al., this issue). Surface water was oxygen supersaturated (Figure $5 \mathrm{~g}$ ), in agreement with a seawater $\mathrm{CO}_{2}$ content in the upper 30 meters strongly under atmospheric level (Figure 5f).

Although no subsurface Chl $a$ maximum was distinguished in the central zone during FRUELA 96 (Figure 5h), Chl $a$ reached $4 \mathrm{mg} \cdot \mathrm{m}^{-3}$ at 40m depth, indicating once again an accumulation of phytoplankton biomass near the Scholaert Strait channel. Accordingly, $\mathrm{pCO}_{2}$ and $\mathrm{AOU}$ isolines turned considerably downwards as they did 
during the previous survey in the same area, showing the influence of the influx across the Scholaert Strait.

Surface $\mathrm{pCO}_{2}$ and $\mathrm{AOU}$ were significantly correlated $\left(\Delta \mathrm{pCO}_{2} / \Delta \mathrm{AOU}=1.25 \pm\right.$ $\left.0.27, \mathrm{r}^{2}=0.85, \mathrm{p}<0.0093\right)$. Therefore, biological activity was probably mainly controlling the $\mathrm{CO}_{2}$ content in the Gerlache Strait during early January 96.

Air-sea fluxes in the Gerlache Strait area are shown in figure 6. Regarding air-sea $\mathrm{CO}_{2}$ exchange, this area acted as a mean sink for atmospheric $\mathrm{CO}_{2}\left(-3.8 \mathrm{mmol} \cdot \mathrm{m}^{-2} \cdot \mathrm{d}^{-1}\right.$, table 1) during December 95, with the highest uptake of $\mathrm{CO}_{2}$ in the central area (Figure 6a). During early January 96, the mean $\mathrm{CO}_{2}$ influx in the Gerlache Strait changed to -16 mmol. $\mathrm{m}^{-2} \cdot \mathrm{d}^{-1}$ (Table 1 ), and in contrast to the previous survey the highest fluxes were recorded at the limits of the strait, where elevated air-sea gradients were reported.

No significant correlation was found between oxygen and $\mathrm{CO}_{2}$ fluxes (Figure 6) in Ger'95. Both fluxes showed the highest values in the same direction at the central area.

Oxygen fluxes in early January 96 (Figure 6b) presented an inverse pattern to those of $\mathrm{CO}_{2}$ following the equation:

$$
\mathrm{FCO}_{2}( \pm 5.8)=-4.6( \pm 3.4)-0.22( \pm 0.05) \cdot \mathrm{FO}_{2}, \mathrm{r}^{2}=0.85, \mathrm{p}<0.0083
$$

As during Macro'95, once oxygen is equilibrated, there should be a residual flux of $\mathrm{CO}_{2}$ into the ocean.

\section{Temporal changes of $\mathrm{CO}_{2}$ in surface water}

Another method to asses the processes governing the variability of surface $\mathrm{CO}_{2}$ content is separating $\mathrm{CO}_{2}$ temporal changes according to the formulation of Poisson et al. (1993) and Bakker et al. (1997):

$$
\Delta \mathrm{f} / \Delta \mathrm{t}=[\partial \mathrm{f} / \partial \mathrm{t}]_{\mathrm{T}}+[\partial \mathrm{f} / \partial \mathrm{t}]_{\mathrm{F}}+[\partial \mathrm{f} / \partial \mathrm{t}]_{\mathrm{R}}
$$

where $\mathrm{f}$ stands for $\mathrm{CO}_{2}$ fugacity, $\Delta \mathrm{f} / \Delta \mathrm{t}$ is the temporal $\mathrm{fCO}_{2}$ variations during the period $\Delta \mathrm{t}$, which are the sum of variations due to thermodynamic changes (those related to temperature and salinity, $\left.[\partial \mathrm{f} / \partial \mathrm{t}]_{\mathrm{T}}\right)$, air-sea exchanges $\left([\partial \mathrm{f} / \partial \mathrm{t}]_{\mathrm{F}}\right)$ and a residual term $\left([\partial f / \partial t]_{R}\right)$ ascribed to the combined effects of biological activity, mixing, upwelling and variability of water masses in the studied region. Following this formulation, we will calculate the temporal changes (in this case daily) in surface $\mathrm{pCO}_{2}$ from FRUELA 95 to 96 in the Bellingshausen Sea (Belling.), Bransfield (Bransf.) and Gerlache (Ger.) Strait domains (Figure 1a, table 2). 
Here we assumed an ideal-gas behaviour of $\mathrm{CO}_{2}$ as the difference between $\mathrm{fCO}_{2}$ and $\mathrm{pCO}_{2}$ is about $0.7 \%$ (Weiss, 1974). Therefore the three first terms in equation (8) can be quantified by measurements made on board. Thus, the residual daily change of $\mathrm{pCO}_{2}$ can be computed and ascribed to vertical turbulent diffusion and biological activity, neglecting water-masses mixing and upward motion (Gomis et al., this issue) (Table 2).

The estimated error for $\Delta \mathrm{pCO}_{2} / \Delta \mathrm{t}$ is about $\pm 25 \%$. The daily thermodynamic change of surface $\mathrm{pCO}_{2},\left(\left[\partial \mathrm{pCO}_{2} / \partial \mathrm{t}\right]_{\mathrm{T}}\right)$, was calculated using the $\mathrm{CO}_{2}$ system equations and constants referred in the "Materials and methods" section. The estimated maximum relative error for $\left[\partial \mathrm{pCO}_{2} / \partial \mathrm{t}\right]_{\mathrm{T}}$ was about $\pm 58 \%$. The daily change of surface $\mathrm{pCO}_{2}$ due to air-sea exchange $\left(\left[\delta \mathrm{pCO}_{2} / \delta \mathrm{t}\right]_{\mathrm{F}}\right)$, was estimated according to Bakker et al. (1997) as:

$$
\left[\partial \mathrm{pCO}_{2} / \partial \mathrm{t}\right]_{\mathrm{F}}=-\mathrm{F}_{\mathrm{av}} \cdot \beta \cdot \mathrm{pCO}_{2 \mathrm{w}} \cdot \mathrm{TTIC}^{-1}
$$

where $\mathrm{F}_{\mathrm{av}}$ and $\mathrm{pCO}_{2 \mathrm{w}}$ are the average air-sea exchange an surface $\mathrm{pCO}_{2}$ respectively, $\beta$ the buffer or Revelle factor and TTIC is the average total amount of total inorganic carbon (TIC) in the mixed layer at the beginning of the period for each domain.

The average air-sea flux $F_{a v}$ was calculated as the average of fluxes for each domain. $\mathrm{pCO}_{2 \mathrm{w}}$ is the average surface $\mathrm{CO}_{2}$ content for each domain and the Revelle factor $\beta\left(\beta=\delta \ln \left(\mathrm{pCO}_{2}\right) / \delta \ln (\mathrm{TIC})\right)$ was computed from surface measurements in each domain and period.

TTIC was calculated according to Bakker et al. (1997), as the product of the average TIC in the mixed layer, the mixed layer depth and the density for the beginning of each period. Mixed layer depths were estimated form CTD profiles using the criterion of Mitchel and Holm-Hansen (1991) (Castro et al., this issue). The relative error of $\left[\partial \mathrm{pCO}_{2} / \partial \mathrm{t}\right]_{\mathrm{F}}$ was $\pm 27 \%$.

Taking into account the estimated errors for the total, thermodynamic and the airsea terms the maximum relative error for the residual term was about $\pm 33 \%$.

In the Belling. domain surface $\mathrm{pCO}_{2}$ increased at $0.65 \mu \mathrm{atm} . \mathrm{d}^{-1}$ between FRUELA 95 and 96. This change corresponded to the combined effect of the $\mathrm{CO}_{2}$ air to sea entry $\left(0.21 \mu \mathrm{atm} . \mathrm{d}^{-1}\right)$ and to the raise in $1.9^{\circ} \mathrm{C}$ of surface temperature (as salinity effect was negligible, <1 $4 \mathrm{~atm}$ in 51 days) leading to an increase in $0.35 \mu \mathrm{atm} . \mathrm{d}^{-1}$. The residual daily changes of $\mathrm{pCO}_{2}$ were small for this domain. 
In the Bransfield Strait domain surface $\mathrm{pCO}_{2}$ decreased at a rate of $-0.59 \mu$ atm. $\mathrm{d}^{-1}$. As air-sea $\mathrm{CO}_{2}$ exchange influence was small, this change would have been almost twice as large, if the increase in $1.3^{\circ} \mathrm{C}$ of surface temperature had not counteracted the decrease in $0.39 \mu \mathrm{atm} \cdot \mathrm{d}^{-1}$. Residual daily changes in this area can be attributed to net phytoplankton uptake of dissolved $\mathrm{CO}_{2}$ as suggested, by the increase in nutrients anomalies in this area between FRUELA 95 and 96 (Castro et al., this issue).

In absolute terms, the Gerlache Strait presented the highest daily variation in surface $\mathrm{pCO}_{2}\left(-1.75 \mu \mathrm{atm} . \mathrm{d}^{-1}\right.$, table 2). The observed high reduction in surface $\mathrm{pCO}_{2}$ would have been even larger if air-sea exchange of $\mathrm{CO}_{2}$ had not added $1.15 \mu$ atm.d ${ }^{-1}$, resulting in a residual daily change of $-2.9 \mu \mathrm{atm} . \mathrm{d}^{-1}$. The large decrease in surface $\mathrm{pCO}_{2}$ in this area from December 95 to January 96 can be related to phytoplankton $\mathrm{CO}_{2}$ uptake as suggested by the increases in surface mean Chl $a$ between FRUELA 95 and 96 from 3.9 to $8.3 \mathrm{mg} \cdot \mathrm{m}^{-2}$ (Table 1), nutrient depletions (Castro et al., this issue) and primary productivity (Varela et al., this issue). Therefore, during this period the influence on $\mathrm{pCO}_{2}$ of biological activity exceeded that due to physical processes.

\section{Temporal changes of total inorganic carbon in the upper mixed layer}

The total $\mathrm{CO}_{2}$ content (TIC) in the upper mixed layer (UML) is controlled by the following processes: the air-sea $\mathrm{CO}_{2}$ exchange, the biological $\mathrm{CO}_{2}$ uptake/ respiration, advective transport of water and diffusive transport of $\mathrm{CO}_{2}$ (Chipman et al., 1993). In the previous section residual daily changes of $\mathrm{pCO}_{2}$ in the surface layer $\left(\left[\partial \mathrm{pCO}_{2} / \partial \mathrm{t}\right]_{\mathrm{R}}\right)$ have been estimated and ascribed to biological activity and vertical advection. In this section, according to the formulation of Bakker et al. (1997), we will obtain net residual daily changes of TIC in the UML for each domain, which can be calculated from $\left[\partial \mathrm{pCO}_{2} / \partial \mathrm{t}\right]_{\mathrm{R}}\left(\mathrm{R}_{\mathrm{pCO} 2}\right)$, or directly from TIC changes in the UML, once corrected for airsea exchange $\left(\mathrm{R}_{\mathrm{TIC}}\right)$ (Table 3$)$.

As commented in section 3, residual daily changes $(\mathrm{R})$ were attributed to upward diffusion (U) and biological activity. Biological activity accounts for primary production (P) minus mineralization (M), or for biomass increase (B) plus export due to sedimentation $(\mathrm{E})$. Therefore:

$\mathrm{R}=$ Upward transport $(\mathrm{U})-$ Primary production $(\mathrm{P})+$ Mineralization $(\mathrm{M})$

$=$ Upward transport $(\mathrm{U})-$ Biomass increase $(\mathrm{B})-$ Export $(\mathrm{E})$ 
Residual daily changes based on $\mathrm{pCO}_{2}$ were calculated using the formula:

$$
\mathrm{R}_{\mathrm{pCO} 2}=\left[\partial \mathrm{pCO}_{2} / \partial \mathrm{t}\right]_{\mathrm{R}} \cdot \mathrm{TTIC} \cdot \beta^{-1} \cdot \mathrm{pCO}_{2 \mathrm{w}}{ }^{-1}
$$

where all these parameters have been defined in the previous section and taken from table 2 for each domain. The estimated relative error for this new variable was about $\pm 65 \%$ from its mean value. Residual daily changes of TIC $\left(\mathrm{R}_{\Delta \mathrm{TIC}}\right)$ in the upper mixed layer were also obtained from changes of TIC in the UML once corrected for the air-sea exchange $\left(\mathrm{R}_{\text {TIC }}\right)$. The maximum relative error of $\mathrm{R}_{\text {TIC }}$ was about $\pm 31 \%$ from its mean value.

The upward flux of TIC was evaluated from:

$$
\mathrm{U}=-\mathrm{Kz} \cdot(\delta \mathrm{TIC} / \delta \mathrm{z})
$$

where $\mathrm{Kz}$ is the eddy diffusivity coefficient, with a value of $0.5 \mathrm{~cm}^{2} . \mathrm{s}^{-1}$ (Gordon et al., $1984)$ and $(\delta \mathrm{TIC} / \delta \mathrm{z})$ is the gradient of TIC between the upper mixed layer depth and $100 \mathrm{~m}$, where the maximum gradient in the TIC profiles has been found (Castro et al., this issue). The lowest upward fluxes of TIC into the mixed layer were calculated for the Bransfield domain (1.8 mmol. $\mathrm{m}^{-2} \cdot \mathrm{d}^{-1}$, table 3), whereas in the Gerlache and Bellingshausen domains greater TIC gradients leaded to upward fluxes about three fold higher.

Values of ${ }^{14} \mathrm{C}$ primary production $(\mathrm{P})$ in the UML were obtained from Varela et al. (this issue). Biomass increases were calculated solely from particulate organic carbon (POC) changes in the mixed layer (Castro et al., this issue). Changes in the dissolved organic carbon (DOC) content have been neglected assuming uniformity with time (Kähler et al., 1997, Bakker et al., 1997) due to the lack of data for the FRUELA 96 cruise.

Residual daily changes of TIC based on $\mathrm{pCO}_{2}$ suggested a net TIC increase in the UML content of $2.2 \mathrm{mmol} . \mathrm{m}^{-2} \cdot \mathrm{d}^{-1}$ in the Belling. Domain (Table 3). Residual daily changes based on TIC without correction for air-sea exchange $\left(\mathrm{R}_{\Delta \text { TIC }}\right)$ (Table 3) indicated that in this domain there was a gain in the TIC content of the UML, however the large mean air-sea $\mathrm{CO}_{2}$ flux in this area during both FRUELA cruises almost cancelled out this increase giving rise to a slightly net decrease $\left(R_{T I C}=-0.3 \mathrm{mmol} . \mathrm{m}^{-2} \cdot \mathrm{d}^{-}\right.$ ${ }^{1}$ ). Biomass decreased and although there was upward advection of TIC, the latter was supposed to decrease in the upper mixed layer, by export from the UML at a rate of 9 mmol. $\mathrm{m}^{-2} \cdot \mathrm{d}^{-1}$. However, we lack of sediment trap data to confirm this conjecture. 
The higher uncertainty committed when calculating residual changes of carbon based on $\mathrm{R}_{\mathrm{pCO} 2}$, led us to use $\mathrm{R}_{\mathrm{TIC}}$ for estimating the mineralization and export rate of carbon (Table 3). Despite the large difference, $\mathrm{R}_{\mathrm{pCO} 2}$ and $\mathrm{R}_{\mathrm{TIC}}$ suggest a net decrease of TIC in the UML of the Bransf. domain between FRUELA 95 and 96. Estimated values of mineralization indicate that $87 \%$ of primary productivity was recycled in the mixed layer, and about $12 \%$ exported from it (Table 3). And as in the previous area no sediment trap data were collected.

The two methods for calculating residual daily changes of TIC gave higher and more consistent values for the Gerlache domain. These results were in agreement with the elevated changes of POC (Table 3, dPOC) in the UML of this area. The high values of primary productivity and residual daily changes of TIC reported suggest low efficiency of carbon recycling. The estimated mineralization and export constituted $14 \%$ and $58 \%$ of primary production, respectively. Conversely to the other areas, we have available data from sediment traps (Anadón et al., this issue), our estimated carbon exported from the euphotic zone $\left(23.5 \mathrm{mmol} . \mathrm{m}^{-2} \cdot \mathrm{d}^{-1}\right.$ using $\mathrm{R}_{\mathrm{TIC}}$ and $19.5 \mathrm{mmol} \cdot \mathrm{m}^{-2} \cdot \mathrm{d}^{-1}$ using $\mathrm{R}_{\mathrm{pCO} 2}$, table 3 ) is within the range obtained by these authors, 19.8-86.6 mmol.m ${ }^{-}$ ${ }^{2} . \mathrm{d}^{-1}$, supporting our estimated values of $\mathrm{R}_{\mathrm{TIC}}$ and $\mathrm{R}_{\mathrm{pCO} 2}$.

\section{Discussion}

$p \mathrm{CO}_{2}$ distribution and controlling factors

The results presented in this paper for different areas of the Southern Ocean (Bransfield and Gerlache Straits and Bellingshausen Sea) show that surface $\mathrm{pCO}_{2}$ distribution and controlling factors during the same season vary spatially and temporalily. Thus, supporting the idea of the Southern Ocean as a "mosaic" of subsystems (Tréguer and Jacques, 1992; Robins et al., 1995; Castro et al., this issue).

\section{Bellingshausen Sea domain}

Frontal regions in the Southern Ocean are highly productive zones and support high concentrations of phytoplankton (Bianchi et al., 1992; Laubscher et al., 1993; Turner and Owens, 1995; Smetacek et al., 1997). In this sense, the most important feature of the Bellingshausen Sea area is the presence of the SbyACC (García et al., this issue), which was associated with high biomass accumulation and substantial $\mathrm{pCO}_{2}$ depletion during FRUELA 95. A similar situation was also reported for this region during austral spring/summer 1992 (Robertson and Watson, 1995; Bellerby et al., 
1995). These authors found a significant linear correlation between surface $\mathrm{pCO}_{2}$ and chlorophyll suggesting that photosynthetic $\mathrm{CO}_{2}$ uptake was responsible for the reduction of surface $\mathrm{pCO}_{2}$. In our study, we came to the same conclusion from the significant correlation between surface $\mathrm{pCO}_{2}$ and $\mathrm{AOU}$. However, no clear relationship was observed between surface $\mathrm{pCO}_{2}$ and $\mathrm{Chl} a$. Chl $a$ is affected by sedimentation and grazing processes, thus it is not a conservative parameter. Despite the lack of correlation between $\mathrm{pCO}_{2}$ and $\mathrm{Chl} a$, the relationship between $\mathrm{pCO}_{2}$ and $\mathrm{AOU}$ points to biological activity as the main process controlling $\mathrm{pCO}_{2}$ distribution. A similar relationship between $\mathrm{pCO}_{2}$ and oxygen was found in other systems as a coastal embayment affected by upwelling (Álvarez et al., 1999), the Bering Sea (Codispoti et al., 1982), the Bay of Bengal (George et al., 1994) and the North Atlantic ocean (Robertson et al., 1993).

Despite physico-dynamic conditions in late January 96 remained practically the same as during December 95 no occurrence of a phytoplankton bloom was reported, probably as a result of a combination of factors as light and iron limitation, grazing pressure, etc (Estrada and Anadón, this issue). Mean surface Chl $a$ concentration was reduced from 1.7 to $0.45 \mathrm{mg} \cdot \mathrm{m}^{-3}$. Mean surface $\mathrm{pCO}_{2}$ increased from 280 to $313 \mu \mathrm{atm}$. The low $\mathrm{pCO}_{2}$ levels found during late January 96 in the Belling. domain may still reflect the photosynthetic $\mathrm{CO}_{2}$ uptake 51 days before. The budget calculations suggest that the increase in $\mathrm{pCO}_{2}$ was mainly the result of seasonal warming and air-sea exchange.

Estimated residual daily changes of surface $\mathrm{pCO}_{2}$ were practically negligible from FRUELA 95 to 96 in this area. Hence these evidences suggest that the shift in surface $\mathrm{pCO}_{2}$ in the Belling. domain from FRUELA 95 to 96 can be accounted for mainly by physical rather than biological factors.

\section{$\underline{\text { Bransfield Strait domain }}$}

In early December 95 the Bransfield Strait region during the Macro'95 survey was characterised by high mean surface concentrations of Chl $a\left(1.7 \mathrm{mg} \cdot \mathrm{m}^{-3}\right)$ and AOU (12 $\mu$ mol. $\mathrm{kg}^{-1}$ ) associated with a value of $\mathrm{pCO}_{2}$ above the atmospheric level (372 $\mu \mathrm{atm}$ ). Bellerby et al. (1995) found during spring 1992 similar values of $\mathrm{pCO}_{2}$ related to low chlorophyll concentrations and attributed them to remnants of upwelled $\mathrm{CO}_{2}$-rich Circumpolar Deep Water during austral winter. The above may also explain our high values of surface $\mathrm{pCO}_{2}$ in early December 95 . An alternative explanation is advection or 
transport by the Bransfield current of $\mathrm{CO}_{2}$-rich surface water with a Weddell Sea origin influenced by Warm Deep Water entrainment (Hoppema, et al., 1995).

About ten days after Macro'95, high concentrations of surface Chl $a$ were found south of the Bransfield front and in the Gerlache-Bransfield confluence during the intensive sampling in the western basin of the Bransfield Strait (Meso'95), supporting the idea of frontal areas as zones favourables for phytoplankton development and accumulation. Despite the lack of correlation between surface $\mathrm{pCO}_{2}$ and either Chl $a$ or AOU concentrations, $\mathrm{pCO}_{2}$ well below atmospheric levels were associated to elevated Chl $a$ values and low values of AOU, suggesting biological drawdown of $\mathrm{CO}_{2}$. In contrast, pre-bloom conditions were found in the Antarctic shelf area (TWW domain). Here shallow mixed layer depths and high stability were accompanied by high values of AOU and nutrients and very low average Chl $a$ in the UML (Castro et al., this issue). So remnants of winter mixing and upwelling of $\mathrm{CO}_{2}$-rich deep water before the cruise may explain supersaturated surface $\mathrm{CO}_{2}$-content in this area.

Although mean surface $\mathrm{Chl} a$ concentration was slightly reduced in the Bransfield Strait area from early December 95 to late January 96, mean surface $\mathrm{pCO}_{2}$ decreased by $30 \mu \mathrm{atm}$ (Table 2). Despite the lack of relationship between $\mathrm{pCO}_{2}$ and $\mathrm{AOU}$ and between $\mathrm{pCO}_{2}$ and $\mathrm{Chl} a$ during Macro'96, this change can be ascribed to biological activity, as suggested not only by our estimates of the daily residual change of $\mathrm{pCO}_{2}$ (Table 2, 3), but also by the increase in the estimated nutrient and TIC anomalies of the upper mixed layer (Castro et al., this issue).

The Bransfield Strait, without the area near Livingston I., in late January 96 had a mean $\mathrm{pCO}_{2}$ of $331 \pm 11 \mu$ atm, value very similar to that reported by Karl et al. (1991) during January 1987 on the RACER study ( $\geq 325 \mu \mathrm{atm}$ ).

\section{Gerlache Strait domain}

This sheltered area had the highest biomass accumulations during both cruises, associated with high water column stability and shallow upper mixed layers (Castro et $a l$. , this issue). Primary production values during both surveys were notably high (Varela et al., this issue), as well as nutrients anomalies (Castro et al., this issue). These evidences corroborate the idea of $\mathrm{CO}_{2}$ uptake by photosynthesis as the main factor controlling $\mathrm{pCO}_{2}$ distributions, as suggested the high correlation between $\mathrm{AOU}$ and $\mathrm{pCO}_{2}$ during Gerlache 96 and the high and negative value of residual daily changes of surface $\mathrm{pCO}_{2}$ (Table 2) between the 95 and 96 surveys. 


\section{Air-sea fluxes}

It is well know that the uncertainty in the transfer velocity algorithms exceeds any other source of error in the estimation of air-sea exchange (Wanninkhof, 1992; Lundgberg, 1994; Robertson and Watson, 1995; Takahashi et al., 1997). In this sense, if air-sea $\mathrm{CO}_{2}$ fluxes for the FRUELA cruises were calculated using the Wanninkhof (1992) relationship for spot winds they would be almost a factor of two higher.

A mean flux of $-3.35 \cdot 10^{-3} \mathrm{MtC} . \mathrm{d}^{-1}$ (thus about $-4.8 \cdot 10^{-14} \mathrm{MtC} \cdot \mathrm{m}^{-2} \cdot \mathrm{d}^{-1}$ for the 52 days and $7.10^{10} \mathrm{~m}^{2}$ of the survey) was calculated for the Bellingshausen Sea and Bransfield Strait during the FRUELA cruises. Therefore the surveyed area acted as a mean sink during austral 1995-96 spring/summer season, however, the large standard deviation suggest a great variation in the magnitude of the flux, which can be accounted for by local and short-time variations in the value and direction of the fluxes. A similar conclusion was reached by Metzl et al. (1991) in the south-west Indian sector of the Southern Ocean during summer 1987. Our estimated mean flux agrees well when compared to that given by Robertson and Watson (1995) from cruise tracks in the Bellingshausen Sea $\left(88^{\circ} \mathrm{W}\right.$ ) and between $20^{\circ}$ and $60^{\circ} \mathrm{E}$ (area about $9.10^{10} \mathrm{~m}^{2}$ ) during spring to late summer $1992 / 93\left(-0.36 \mathrm{MtC} \cdot \mathrm{d}^{-1}\right.$, thus about $\left.-4.10^{-14} \mathrm{MtC} \cdot \mathrm{m}^{-2} \cdot \mathrm{d}^{-1}\right)$. At the same time our mean daily flux (mean \pm STD) $\left(-3.4 \pm 5.1\right.$ mmol.m $\left.\mathrm{m}^{-2} \cdot \mathrm{d}^{-1}\right)$ compared to the value given by Bakker et al. (1997) $\left(0.3 \mathrm{mmol} . \mathrm{m}^{-2} . \mathrm{d}^{-1}\right)$ for consecutive sections between $47^{\circ}$ and $60^{\circ} \mathrm{S}$ along $6^{\circ} \mathrm{W}$ in October-November 1992 is noticeably much higher. Regarding the Gerlache Strait, its mean $\mathrm{CO}_{2}$ flux was $-9.6 \pm 11.3 \mathrm{mmol} \cdot \mathrm{m}^{-2} \cdot \mathrm{d}^{-1}$, the highest of the three defined domains and, once again very variable. These evidences support the idea of the Southern Ocean as a compendium of different subsystems, which may cover a small fraction of the Southern Ocean but constitute significant spring/summer sinks for atmospheric $\mathrm{CO}_{2}$. Moreover, this emphasizes the need of not only winter surveys, but also of careful studies of subareas in order to estimate a reliable annual flux for the Southern Ocean.

Inverse linear correlations between air-sea $\mathrm{CO}_{2}$ and $\mathrm{O}_{2}$ fluxes were found during the Macro'95 and Ger'96 surveys. Moreover, the value of the slope of these correlations was quite similar $\left(\Delta \mathrm{FO}_{2} / \Delta \mathrm{FCO}_{2} \approx 6\right)$. This situation was accompanied by high rates of primary production (Varela et al., this issue) and significant correlations between AOU 
and $\mathrm{pCO}_{2}$. Therefore, the development and subsistence of phytoplanktonic blooms seems to control the existence of covariation between air-sea $\mathrm{CO}_{2}$ and $\mathrm{O}_{2}$ fluxes.

Biologically induced air-sea fluxes of $\mathrm{CO}_{2}$ are 15 times smaller than fluxes of $\mathrm{O}_{2}$ (Keeling et al, 1993). However, during Macro'95 and Ger'96 we obtained a lower relationship between both fluxes, suggesting other processes influencing the air-sea fluxes.

Temporal changes of $\mathrm{TIC}$ and $\mathrm{pCO}$

Residual daily changes of dissolved inorganic carbon between FRUELA 95 and 96 for the Bransfield Strait and the Bellingshausen Sea based on TIC ( $\mathrm{R}_{\text {TIC }}$ ) and on $\mathrm{pCO}_{2}\left(\mathrm{R}_{\mathrm{pCO} 2}\right)$ differed considerably (Table 3$)$. This fact can be attributed to the relatively high uncertainty committed in estimates of both variables $(65 \%$ and $31 \%$ respectively). However, the higher residual daily changes of $\mathrm{pCO}_{2}$ and TIC ( $\mathrm{R}_{\mathrm{TIC}}$ and $\mathrm{R}_{\mathrm{pCO} 2}$ in table 3) corresponded rather well in the Ger. domain. In this area, the indirect estimation of the exported carbon from the euphotic zone was confirmed by direct sediment trap measurements. This is an encouraging result, as it supports an indirect reliable method for estimating the carbon flux out of the mixed layer in areas with large temporal changes.

\section{Conclusions}

The results support the idea of $\mathrm{pCO}_{2}$ as a complex variable, whose distribution stems from the combination of physical and biological factors (Bakker et al., 1997; Brewer, 1986; Poisson et al., 1993; Takahashi et al., 1993; Watson et al., 1991). The predominance of one of these factors varies in space and time, even during the same season in a limited area of the Atlantic Sector of the Southern Ocean (Bakker et al, 1997; Hoppema et al., 1995; Robertson and Watson, 1995).

In this sense, the three hydrographic regions (Bransfield and Gerlache Straits and Bellingshausen Sea domains) differ in the processes controlling surface $\mathrm{pCO}_{2}$ variability. Phytoplankton $\mathrm{CO}_{2}$ uptake during an intense diatom bloom controlled $\mathrm{CO}_{2}$ distribution in the frontal area of the SbyACC in early December 95. A similar situation was reported for the sheltered area of the Gerlache Strait, specially in late January 96. During periods of strong bloom development, $\mathrm{CO}_{2}$ and $\mathrm{O}_{2}$ fluxes presented a significant inverse correlation, implying a biological induced air-sea exchange of both variables. 
On the other hand, seasonal warming dominated the increase of surface $\mathrm{pCO}_{2}$ from early December 95 to late January 96 in the Bellingshausen Sea area.

Carbon export obtained from sediment trap data supported the calculated budget for total dissolved inorganic carbon in the mixed layer of the Gerlache Strait. In areas where the signal to noise ratio of the dissolved inorganic carbon residual changes are large enough, the residual changes in the upper mixed layer of TIC, based on $\mathrm{pCO}_{2}$ and directly on TIC, agree.

A mean daily $\mathrm{CO}_{2}$ flux of (mean \pm STD) $-3.4 \pm 5.1 \mathrm{mmol} \cdot \mathrm{m}^{-2} \cdot \mathrm{d}^{-1}$ was estimated for the whole period and area surveyed. Despite acting as a mean sink for atmospheric $\mathrm{CO}_{2}$, the high standard deviation of this estimation confirms the different $\mathrm{CO}_{2}$ flux direction and magnitude reported for each domain and period. Moreover, apart from the need of winter-time studies, points to the importance of subareas of the Southern Ocean in the estimation of an annual basin-wide $\mathrm{CO}_{2}$ flux for the Southern ocean.

\section{Acknowledgements.}

The authors would like to express their gratitude to the crew, officers and technical staff of BIO Hésperides for their help during sampling at sea and to all participants in the FRUELA cruises. Our special thanks to T. Rellán and MV. González for the $\mathrm{CO}_{2}$ and oxygen analyses performed during the cruises. Thanks to M. Varela for providing primary productivity data, and our special gratitude to C.G. Castro for calculating UML depths and gradient data and also to her, F.F. Pérez and X.A. ÁlvarezSalgado for their valuable comments and suggestions. Constructive reviews by $\mathrm{M}$. González Dávila and D.C.E. Bakker helped refine this paper. Meteorological data were obtained from Jordi Sorribas (UGBO) and atmospheric $\mathrm{CO}_{2}$ data were kindly reported from T. Conway (CDML). This work was funded by CYCIT contract nº ANT94-1010. 


\section{Table 1}

Surface mean values and standard deviation of temperature $\left({ }^{\circ} \mathrm{C}\right), \mathrm{pCO}_{2}$ ( $\left.\mu \mathrm{atm}\right)$, chlorophyll $a\left(\mathrm{mg} \cdot \mathrm{m}^{-3}\right)$ and AOU $\left(\mu \mathrm{mol} . \mathrm{kg}^{-1}\right)$, wind speed $\left(\mathrm{m} . \mathrm{s}^{-1}\right)$ and air-sea $\mathrm{CO}_{2}$ and $\mathrm{O}_{2}$ fluxes (both in mmol.m $\mathrm{m}^{-2} \cdot \mathrm{d}^{-1}$ ) for the different domains (Figure 1a). Bransf. and Ger. stand for the Bransfield and the Gerlache Strait domains respectively, and Belling. for the Bellingshausen Sea domain.

\begin{tabular}{ccccccc}
\hline Domain & Belling. 95 & Belling. 96 & Bransf. 95 & Bransf. 96 & Ger. 95 & Ger. 96 \\
\hline $\mathrm{T}^{\mathrm{a}}\left({ }^{\circ} \mathrm{C}\right)$ & $-0.14( \pm 0.29)$ & $1.77( \pm 0.35)$ & $-0.51( \pm 0.34)$ & $0.82( \pm 0.72)$ & $0.22( \pm 1)$ & $0.68( \pm 0.58)$ \\
$\mathrm{pCO} 2(\mu \mathrm{atm})$ & $280( \pm 49)$ & $313( \pm 17)$ & $372( \pm 10)$ & $342( \pm 26)$ & $312( \pm 26)$ & $241( \pm 22)$ \\
$\mathrm{Chl} a\left(\mathrm{mg} \cdot \mathrm{m}^{-3}\right)$ & $1.7( \pm 1.17)$ & $0.45( \pm 0.35)$ & $1.69( \pm 0.59)$ & $1.13( \pm 0.46)$ & $3.86( \pm 1.76)$ & $8.25( \pm 2.97)$ \\
$\mathrm{AOU}\left(\mu \mathrm{mol} \cdot \mathrm{kg}^{-1}\right)$ & $-19( \pm 20)$ & $1( \pm 4)$ & $12( \pm 12)$ & $5( \pm 5)$ & $1( \pm 24)$ & $-23( \pm 16)$ \\
$\mathrm{Wind} \mathrm{speed}\left(\mathrm{m}_{\mathrm{s}} \mathrm{s}^{-1}\right)$ & $7( \pm 3)$ & $7( \pm 2)$ & $8( \pm 2)$ & $6( \pm 1)$ & $6( \pm 4)$ & $9( \pm 4)$ \\
$\begin{array}{c}\mathrm{F} \mathrm{CO} \\
\left(\mathrm{mmolC} \cdot \mathrm{m}^{-2} \cdot \mathrm{d}^{-1}\right)\end{array}$ & $-6.5( \pm 6.0)$ & $-4.0( \pm 2.6)$ & $1.3( \pm 1.1)$ & $-0.9( \pm 1.6)$ & $-3.8( \pm 4.2)$ & $-15.9( \pm 13.7)$ \\
$\left.\begin{array}{c}\mathrm{F} \mathrm{O}_{2} \\
(\mathrm{mmolO}\end{array} \mathrm{m}^{-2} \cdot \mathrm{d}^{-1}\right)$ & $25( \pm 29)$ & $-2( \pm 6)$ & $-18( \pm 21)$ & $-5( \pm 5)$ & $-12( \pm 32)$ & $53( \pm 59)$ \\
\hline
\end{tabular}




\section{Table 2}

Changes of surface $\mathrm{pCO}_{2}$ between FRUELA 95 and 96 in the three different domains defined. Variables used in the calculations: the time interval ( $\Delta \mathrm{t})$, mixed layer (ML) depth, changes in surface temperature $(\Delta \mathrm{T})$ and $\mathrm{pCO}_{2}\left(\Delta \mathrm{pCO}_{2}\right)$, average surface $\mathrm{CO}_{2}$ content in each domain $\left(\mathrm{pCO}_{2 \mathrm{w}}\right)$ and $\mathrm{CO}_{2}$ flux (Fav), buffer factor $(\beta)$ and depth integrated total dissolved inorganic carbon in the mixed layer (TTIC). Observed daily changes of $\mathrm{pCO}_{2}(\Delta \mathrm{p} / \Delta \mathrm{t})$ are the sum of daily changes due to air-sea exchange $\left([\delta \mathrm{p} / \delta \mathrm{t}]_{\mathrm{F}}\right)$, thermodynamical $\left([\delta \mathrm{p} / \delta \mathrm{t}]_{\mathrm{T}}\right)$ and residual changes $\left([\delta \mathrm{p} / \delta \mathrm{t}]_{\mathrm{R}}\right)$ according to equation (8). See table 1 for abbreviations of the domains.

\begin{tabular}{lcccccccccccc}
\hline & $\begin{array}{c}\Delta \mathrm{t} \\
(\text { days })\end{array}$ & $\begin{array}{c}\mathrm{ML} \\
\mathrm{depth} \\
(\mathrm{m})\end{array}$ & $\begin{array}{c}\Delta \mathrm{T} \\
\left({ }^{\circ} \mathrm{C}\right)\end{array}$ & $\begin{array}{c}\Delta \mathrm{pCO}_{2} \\
(\mu \mathrm{atm})\end{array}$ & $\begin{array}{c}\mathrm{pCO} \mathrm{W}_{2} \mathrm{~B} \\
(\mu \mathrm{atm})\end{array}$ & $\begin{array}{c}\text { Buffer } \\
\text { factor } \\
\beta\end{array}$ & $\begin{array}{c}\mathrm{TTIC} \\
\left(\mathrm{mol} . \mathrm{m}^{-2}\right)\end{array}$ & $\begin{array}{c}\mathrm{Fav} \\
(\mathrm{mmol} . \\
\left.\mathrm{m}^{-2} \cdot \mathrm{d}^{-1}\right)\end{array}$ & $\begin{array}{c}\Delta \mathrm{p} / \Delta \mathrm{t} \\
\left(\mu \mathrm{atm} \cdot \mathrm{d}^{-1}\right)\end{array}$ & $\begin{array}{c}{[\delta \mathrm{p} / \delta \mathrm{t}]_{\mathrm{F}}} \\
\left(\mu \mathrm{atm} \cdot \mathrm{d}^{-1}\right)\end{array}$ & $\begin{array}{c}{[\delta \mathrm{p} / \delta \mathrm{t}]_{\mathrm{T}}} \\
\left(\mu \mathrm{atm} \cdot \mathrm{d}^{-1}\right)\end{array}$ & $\begin{array}{c}{[\delta \mathrm{p} / \delta \mathrm{t}]_{\mathrm{R}}} \\
\left(\mu \mathrm{atm} \cdot \mathrm{d}^{-1}\right)\end{array}$ \\
\hline Belling. & 50.8 & $35-38$ & 1.91 & 33 & 294.7 & 12.1 & 90.71 & -5.42 & 0.65 & 0.21 & 0.35 & 0.09 \\
Bransf. & 50.6 & $11-14$ & 1.32 & -30 & 355.2 & 12.3 & 41.89 & 0.06 & -0.59 & -0.01 & 0.39 & -0.97 \\
Ger. & 40.7 & $15-17$ & 0.48 & -71 & 274.5 & 13.7 & 32.19 & -9.88 & -1.75 & 1.15 & 0.03 & -2.93 \\
\hline
\end{tabular}




\section{Table 3}

Estimations of terms of equations (10): $\mathrm{R}=\mathrm{U}-\mathrm{P}+\mathrm{M}=\mathrm{U}-\mathrm{B}-\mathrm{E}$ between FRUELA 95 and 96 in each domain. Residual daily changes of total inorganic carbon $(\mathrm{R})$ in the upper mixed layer (UML) were evaluated from measured changes of TIC in the UML $\left(\mathrm{R}_{\Delta \mathrm{TIC}}\right)$ corrected for air-sea exchange $\left(\mathrm{R}_{\mathrm{TIC}}\right)$. In addition, residual daily changes of TIC were evaluated from residual daily changes of surface $\mathrm{pCO}_{2}\left(\mathrm{R}_{\mathrm{pCO} 2}\right)$ (Table 2) using equation (11). Upward transport $\mathrm{U}$, net primary production $\mathrm{P}$ from ${ }^{14} \mathrm{C}$ incubations (Varela et al., this issue) and biomass growth B from POC data (Castro et al., this issue) were calculated as in the text. Apparent mineralization $\mathrm{M}$ and carbon export $E$ were estimated from equations (10), with $R$ relying on $R_{T I C}$ instead of $R_{p C O 2}$. See table 1 for abbreviations of the domains.

\begin{tabular}{|c|c|c|c|c|c|c|c|c|c|c|c|}
\hline & $\begin{array}{c}{ }^{14} \mathrm{C} \\
(\mathrm{mgC} . \\
\left.\mathrm{m}^{-2} \cdot \mathrm{d}^{-1}\right)\end{array}$ & $\begin{array}{c}\mathrm{dPOC} \\
(\mathrm{mmol} \\
\left.. \mathrm{m}^{-3}\right)\end{array}$ & $\begin{array}{c}\mathrm{dTIC} \\
(\mu \mathrm{mol} . \\
\left.\mathrm{kg}^{-1}\right)\end{array}$ & $\begin{array}{c}\mathrm{R}_{\Delta \mathrm{TIC}} \\
(\mathrm{mmol} . \\
\left.\mathrm{m}^{-2} \cdot \mathrm{d}^{-1}\right)\end{array}$ & $\begin{array}{c}\mathrm{R}_{\mathrm{TIC}} \\
(\mathrm{mmol} . \\
\left.\mathrm{m}^{-2} \cdot \mathrm{d}^{-1}\right)\end{array}$ & $\begin{array}{c}\mathrm{R}_{\mathrm{pCO} 2} \\
(\mathrm{mmol} . \\
\left.\mathrm{m}^{-2} \cdot \mathrm{d}^{-1}\right)\end{array}$ & $\begin{array}{c}\mathrm{U} \\
(\mathrm{mmol} . \\
\left.\mathrm{m}^{-2} \cdot \mathrm{d}^{-1}\right)\end{array}$ & $\begin{array}{c}\mathrm{P} \\
(\mathrm{mmol} . \\
\left.\mathrm{m}^{-2} \cdot \mathrm{d}^{-1}\right)\end{array}$ & $\begin{array}{c}\mathrm{M} \\
(\mathrm{mmol} \\
\left.\mathrm{m}^{-2} \cdot \mathrm{d}^{-1}\right)\end{array}$ & $\begin{array}{c}\mathrm{B} \\
(\mathrm{mmol} \\
\left.\mathrm{m}^{-2} \cdot \mathrm{d}^{-1}\right)\end{array}$ & $\begin{array}{c}\mathrm{E} \\
(\mathrm{mmol} \\
\left.\mathrm{m}^{-2} \cdot \mathrm{d}^{-1}\right)\end{array}$ \\
\hline Belling. & --- & -4.5 & 7.0 & 5.2 & -0.3 & 2.2 & 5.4 & --- & --- & -3.3 & 9.0 \\
\hline Bransf. & 483.76 & 1.7 & -11.3 & -2.8 & -2.8 & -9.3 & 1.8 & 34.6 & 29.9 & 0.4 & 4.2 \\
\hline
\end{tabular}




\section{FIGURE CAPTIONS}

Figure 1. Map of the chemical stations sampled during (a) Macro'95 and 96 (b) Meso'95 and (c) Gerlache 95 and 96 surveys. Points $(\bullet)$ with plain numbers stand for stations sampled during FRUELA 95 and $(\diamond)$ with underlined numbers for stations sampled during FRUELA 96. The defined domains are limited by dashed lines in figure 1a. On figure 1a are represented the Southern boundary of the Antarctic Circumpolar current (SbyACC), the Southern Polar Front (SPF) and the Bransfield Current (BC). In figure $1 \mathrm{~b}$ are represented the Bransfield Front (BF), the area of Transitional Zonal Water with Bellingshausen influence (TBW) and Transitional Zonal Water with Weddell Sea influence (TWW).

Figure 2. Surface distribution of (a) temperature $\left({ }^{\circ} \mathrm{C}\right)$, (b) chlorophyll a $\left(\mathrm{mg}^{-3} \mathrm{~m}^{-3}\right)$ concentration, (c) AOU ( $\mu$ mol. $\left.\mathrm{kg}^{-1}\right)$, (d) $\mathrm{CO}_{2}$ partial pressure ( $\mu \mathrm{atm}$ ) and air-sea fluxes of (e) oxygen and (f) carbon dioxide during the macroscale 95 sampling. Fluxes are in mmol. $\mathrm{m}^{-2} \cdot \mathrm{d}^{-1}$. The emphasized isoline on figures $2 \mathrm{e}$ and $\mathrm{f}$ indicates a change in the direction of the fluxes. The emphasized isoline on figure $2 \mathrm{~d}$ represents the mean atmospheric $\mathrm{pCO}_{2}$ during the 
sampling period $(358 \mu \mathrm{atm})$. SbyACC stands for Southern boundary of the Antarctic Circumpolar current and BC for the Bransfield Current.

Figure 3. Surface distribution of (a) temperature $\left({ }^{\circ} \mathrm{C}\right)$, (b) chlorophyll a $\left(\mathrm{mg}^{-\mathrm{m}^{-3}}\right)$ concentration, (c) AOU ( $\mu$ mol. $\left.\mathrm{kg}^{-1}\right)$, (d) $\mathrm{CO}_{2}$ partial pressure ( $\mu \mathrm{atm}$ ) and air-sea fluxes of (e) oxygen and (f) carbon dioxide during the mesoscale 95 sampling. Fluxes are in mmol. $\mathrm{m}^{-2} \cdot \mathrm{d}^{-1}$. The emphasized isoline on figures $3 \mathrm{e}$ and $\mathrm{f}$ indicates a change in the direction of the fluxes. The emphasized isoline on figure $3 \mathrm{~d}$ represents the mean atmospheric $\mathrm{pCO}_{2}$ during the sampling period $(358 \mu \mathrm{atm})$. BF stands for Bransfield Front, TBW for Transitional Zonal Water with Bellingshausen influence and TWW for Transitional Zonal Water with Weddell Sea influence.

Figure 4. Surface distribution of (a) temperature $\left({ }^{\circ} \mathrm{C}\right)$, (b) chlorophyll $a\left(\mathrm{mg}^{-3} \mathrm{~m}^{-3}\right)$ concentration, (c) AOU ( $\mu$ mol. $\mathrm{kg}^{-1}$ ), (d) $\mathrm{CO}_{2}$ partial pressure ( $\mu \mathrm{atm}$ ) and air-sea fluxes of (e) oxygen and (f) carbon dioxide during the macroscale 96 sampling. Fluxes are in mmol. $\mathrm{m}^{-2} \cdot \mathrm{d}^{-1}$. The emphasized isoline on figures $4 \mathrm{e}$ and $\mathrm{f}$ indicates a change in the direction of the fluxes. The emphasized isoline on figure $4 \mathrm{~d}$ represents the mean atmospheric $\mathrm{pCO}_{2}$ during the sampling period $(358 \mu \mathrm{atm})$.

Figure 5. Upper $100 \mathrm{~m}$ distributions of (a and e) temperature $\left({ }^{\circ} \mathrm{C}\right)$, (b and $\left.\mathrm{f}\right) \mathrm{pCO}_{2}(\mu \mathrm{atm})$, (c and g) AOU ( $\left.\mu \mathrm{mol} \cdot \mathrm{kg}^{-1}\right)$ and ( $\mathrm{d}$ and g) chlorophyll $a\left(\mathrm{mg} \cdot \mathrm{m}^{-3}\right)$ concentrations in the Gerlache Strait during FRUELA 95 (Ger'95) and 96 (Ger'96). The emphasized isoline on figures 5b and $5 \mathrm{f}$ represents the mean atmospheric $\mathrm{pCO}_{2}$ during the sampling period (358 $\mu \mathrm{atm}$ ).

Figure 6. Air-sea exchange of (a) $\mathrm{CO}_{2}$ and (b) oxygen in the Gerlache Strait during FRUELA 95 (Ger'95) and 96 (Ger'96). Both fluxes in mmol.m $\mathrm{m}^{-2} \cdot \mathrm{d}^{-1}$. 


\section{REFERENCES}

Álvarez, M., E. Fernández and F.F. Pérez (1999) Air-sea $\mathrm{CO}_{2}$ fluxes in a coastal embayment affected by upwelling: physical vs. biological control. Oceanologica Acta 22, 499-515.

Anadón R., E. Fernández, M. Varela, J.M. Gasol, D. Vaqué and M. Zapata (1998). Size dependent particle flux in the antarctic peninsula area". Deep-sea Research II, (submitted).

Andrié, C., C. Oudot, C. Genthon and L. Merlivat, L. (1986). $\mathrm{CO}_{2}$ fluxes in the Tropical Atlantic during FOCAL cruises. Journal of Geophysical Research, 91, 1174111755.

Bakker, D.C.E., H.J.W De Baar and U.V Bathmann (1997). Changes of carbon dioxide in surface waters during spring in the Southern Ocean. Deep Sea Research II, 44, 91-127. 
Bouquegneau, J.M., W.W.C. Gieskes, G.W. Kray and A.M. Larson (1992). Influence of physical and biological processes on the concentration of $\mathrm{O}_{2}$ and $\mathrm{CO}_{2}$ in the ice covered Weddell Sea in the spring of 1988. Polar Biology, 12, 163-170.

Bellerby R.G.J., D.R. Turner and J.E. Robertson (1995). Surface $\mathrm{pH}$ and $\mathrm{pCO}_{2}$ distributions in the Bellingshausen Sea, Southern Ocean during early Austral summer. Deep-sea Research II, 42, 1093-1107.

Bianchi F., A. Boldrin, F. Cioce, G. Dieckmann, H. Kusou, A.M. Larson, E.M. Nöthing, P.I. Shelstedt, G. Socal and E.E. Syverstsen (1992). Phytoplankton distribution in relation to sea ice, hydrography and nutrients in the northwestern Weddell Sea in early spring 1988 during EPOS. Polar Biology, 12, 225-235.

Brewer P.G. (1986). What controls the variability of carbon dioxide in the surface ocean? A plea for complete information. In: Dynamic processes in the chemistry of the upper ocean, J.D. Burton, P.G. Brewer and R. Chesselet, editors, Plenum Press, New York, 246 pp.

Broecker, W.S. and T.H. Peng. (1982). Tracers in the sea. Lamont-Doherty Geological observatory, Palisades, New York.

Castro, C.G., A.F. Rios, M.D. Doval and F.F. Perez.. Spatiotemporal variability of nutrient utilization and chlorophyll distribution in the upper mixed layer during Fruela 95 and FRUELA 96 cruises. Deep-sea Research II, submitted.

Chipman, D.W., J. Marra and T. Takahashi (1993). Primary production at $47^{\circ} \mathrm{N}$ and $20^{\circ} \mathrm{W}$ in the North Atlantic Ocean: a comparison between the ${ }^{14} \mathrm{C}$ incubation method and the mixed layer carbon budget. Deep-sea Research II, 40, 151-169.

Ciais, P., P.P. Tans, J.W.C.White, M. Trolier, R.J. Francey, J.A Berry, D.R. Randall, P.J. Sellers, J.C. Collatz and D.S. Shimel (1995). Partitioning of ocean and land uptake of $\mathrm{CO}_{2}$ as inferred by $\delta^{13} \mathrm{C}$ measurements from the NOAA Climate Monitoring and Diagnostics Laboratory Global Air Sampling Network. Journal of Geophysical Research, 100, 5051-5070.

Codispoti, L.A., G.E. Friederick, R.L. Iverson and D.W. Hood (1982). Temporal changes in the inorganic carbon system of the south-eastern Bering Sea during Spring 1980. Nature, 296, 296-242.

Conway, T.J., P.P. Tans, L.S. Waterman and K.W. Thoning (1994) Evidence for interannual variability of the carbon cycle form the National Oceanic and Atmospheric Administration/Climate Monitoring and Diagnostics Laboratory 
Global Air Sampling Network. Journal of Geophysical Research, 99, 2283122855 .

Dickson, A. G. (1981). An exact definition of total alkalinity and a procedure for the estimation of alkalinity and inorganic total carbon from titration data. Deep-Sea Research, 28, 609-623.

Duursma E.K. and M.P.R.M. Boisson (1994). Global oceanic and atmospheric oxygen stability considered in relation to the carbon cycle and to different time scales. Oceanologica Acta, 17, 117-141.

Estrada, M. and R. Anadón. Introduction to FRUELA cruises. Deep-Sea Research II, (submitted).

García M.A., Ríos, A.F., Castro, C., Doval, M.D., Rosón, G., Gomis, D., and O. López, O. Water masses and distribution of physicochemical properties in the Western basin of the Bransfield Strait and Gerlache Strait dring austral summer 1995/1996. Deep-Sea research II (submitted).

George, M.D., M. Dileep Jkumar, S.W.A. Naqvi, S. Baerjee, P.V. Narvekar, S.N. de Sousa and D.A. Jayakumar (1994). A study of the carbon dioxide system in the northern Indian Ocean during premonsoon. Marine Chemistry, 47, 243-254.

Gomis D., M.A. García, O. López and A. Pascual (1998). Quasi-geostrphic 3D circulations and mass transport in the western sector of the South Shetland Islands. Deep-sea Research II (submitted).

Gordon, A.L., C.T.A. Chen and W.G. Metcalf (1984). Winter mixed layer entrainment of Weddell deep water. Journal of Geophysical research, 89, 637-640.

Hoppema, M., E. Fahrbach, M. Schröder, A. Wisotzki and H. J. W. De Baar (1995). Winter-summer differences of carbon dioxide and oxygen in the Weddel Sea surface layer. Marine Chemistry, 51, 177-192.

Jähne, B., G. Heinz and W. Dietrich (1987). Measurement of the diffusion coefficients of sparingly soluble gases in water with a modified Barrer method. Journal of Geophysical Research, 92, 10767-10776.

Jones E.P., D.M. Nelson and P. Treguer. Chemical Oceanography (1990). In: Polar Oceanography. Part B. Edited by W. O. Smith, Jr. Academic Press, Inc. 407-741.

Kähler P., P.K. Bjornsen, K. Lochte and A. Antia (1997). Dissolved organic matter and its utilization by bacteria during spring in the Southern Ocean. Deep-sea Research II, 44, 341-353. 
Karl, D.M., B.D. Tilbrook and G. Tien (1991). Seasonal coupling of organic matter production and particle flux in the western Bransfield Strait, Antarctica. Deep-Sea Research, 38, 1127-1143.

Keeling R.F., R.P. Najjar, M.L. Bender and P. Tans. (1993). What atmospheric oxygen measurements can tell us about the global carbon cycle. Global Biogeochemical Cycles, 7, 37-67.

Kester, D.R. (1975). Dissolved gasses other than $\mathrm{CO}_{2}$. In: Chemical Oceanography. $2^{\text {nd }}$ edition. Edited by Riley, J.R. and Skirrow, 1, 497-556.

Laubscher R.K., R. Perissinotto and C.D. McQuaid (1993). Phytoplankton production and biomass at frontal zones in the Atlantic sector of the Southern Ocean. Polar Biology, 13, 471-481.

Lee K., F.J. Millero and R. Wanninkof (1997). The carbon dioxide system in the Atlantic Ocean. Journal of Geophysical Research, 102, 15693-15707.

Liss, P. and L. Merlivat (1986). Air-sea exchange rates: Introduction and synthesis. In: The role of Air-sea Exchange in Geochemical Cycling. P. Buat- Ménard, editor, NATO Advanced Science Institutes Series 185, D. Reidel Publishing Company, Dordrecht, Holland, 113-127.

Lundberg, L. (1994). $\mathrm{CO}_{2}$ air-sea exchange in the Nordic Seas. An attempt to make an estimate based on data. Oceanologica Acta, 17, 159-175.

Mehrbach, C., C.H. Culberson, J.E Hawley and R.M. Pytlowicz (1973). Measurements of the apparent dissociation constant of carbonic acid in seawater at atmospheric pressure. Limnology and Oceanography, 18, 897-907.

Metzl N, C. Beauverger, C. Brunet, C. Goyet and A. Poisson (1991). Surface water carbon dioxide in the southwest Indian sector of the Southern Ocean: a highly variable $\mathrm{CO}_{2}$ source/sink region in summer. Marine Chemistry, 35, 85-95.

Millero, F.J. (1995). The Thermodynamics of the carbon dioxide system in the oceans. Geochimica et Cosmochimica Acta, 59, 661-677.

Millero, F.J., Byrne, R.H., Wanninkhof, R., Freely, R., Clayton, T., Murphy, P. and Lamb, M. F., (1994). The internal consistency of $\mathrm{CO}_{2}$ measurements in the equatorial Pacific. Marine Chemistry, 44, 269-280.

Mitchell B.G and O. Holm-Hansen (1991). Observation and modelling of the Antarctic phytoplankton crop in relation to mixing depth. Deep-sea Research II, 38, 9811007. 
Murphy P.P., R. A. Feely, R. H. Gammon, K.C. Kelly and L.S. Waterman (1991a). Autumn air-sea disequilibrium of $\mathrm{CO}_{2}$ in the South Pacific Ocean. Marine Chemistry, 35, 77-84.

Murphy P.P., R. A. Feely, R. H. Gammon, D.E. Harrison, K.C. Kelly and L.S. Waterman (1991b). Assessment of the air-sea exchange of $\mathrm{CO}_{2}$ in the South Pacific during Austral Autumn. Journal of Geophysical Research, 96, 2045520465.

Pérez, F.F. and F. Fraga (1987a). The pH measurements in seawater on NBS scale. Marine Chemistry, 21, 315-327.

Pérez, F. F. and F. Fraga (1987b). A precise and rapid analytical procedure for alkalininity determination. Marine Chemistry, 21, 169-182.

Poisson A., N. Metzl, C. Brunet, B. Schauer, B. Bres, D. Ruiz-Pino and F. Louanchi (1993). Variability of sources and sinks of $\mathrm{CO}_{2}$ in the western Indian and Southern Oceans during the year 1991. Journal of geophysical research, 98, 22759-22778.

Ríos, A.F. and F.F. Pérez (1999). Improvements in potentiometric determinations of $\mathrm{CO}_{2}$ system using seawater sub-standards and $\mathrm{CO}_{2}$ reference materials. Ciencias Marinas, 25, 31-49.

Ríos, A.F. and T. Rellán (1998) pH and alkalinity measurements. In: Recueil de données par Le Groupe CITHER-3. Vol. 3, Traceurs géochimiques. Edited by Laboratoire de Physique des Océans (9803). Brest. France.

Ríos, A.F. and G. Rosón (1996). Surface $\mathrm{pH}$, alkalinity and $\mathrm{pCO}_{2}$ measurements. In: Recueil de données par Le Groupe CITHER-2. Vol.3. Edited by Laboratoire de Physique des Océans (97-02). Brest. France. Pags. 64-72.

Robertson, J.E. and A.J. Watson (1995). A summer-time sink for atmospheric carbon dioxide in the Southern Ocean between $88^{\circ} \mathrm{W}$ and $80^{\circ}$ E. Deep-sea Research II, 42, 1081-1091.

Robertson, J.E., A.J. Watson, C. Langdon, R.D. Ling and J.W. Wood (1993) Diurnal variation in surface $\mathrm{pCO}_{2}$ and $\mathrm{O}_{2}$ at $60^{\circ} \mathrm{N}, 20^{\circ} \mathrm{W}$ in the North Atlantic. Deep-sea Research II, 40, 409-422.

Robins D.B., R.P. Harris, A.W. Bedo, E. Fernández, T.W. Fileman, D.S. Harbour and R.N. Head (1995). The relationship between suspended particulate material, phytoplankton and zooplankton during the retreat of the marginal ice zone in the Bellingshausen Sea. Deep-Sea Research II, 42, 1137-1158. 
Rosón (1992). Flujos y ciclo del carbonato cálcico en la Ría de Arosa. PhD Universidad de Santiago de Compostela, 385 pp.

Roy, R.N., L.N. Roy, K.M. Vogel, C. Porter-Moore, T. Pearson, C.E. Good, F.J. Millero, D.M. Campbell (1993). The dissociation constants of carbonic acid in seawater at salinities 5 to 45 and temperatures 0 to $45^{\circ} \mathrm{C}$. Marine Chemistry, $\mathbf{4 4}$, 249-267.

Rubin, S.I., T. Takahashi, D.W. Chipman and J.G. Goddard (1998). Primary productivity and nutrient utilization ratios in the Pacific sector of the Southern Ocean based on seasonal changes in the seawater chemistry. Deep-Sea Research I, 45, 1211-1234.

Sockal, R.R. and Rolhf, F.J. (1995). Biometry. Freeman, new York, 887 p.

Smetacek V., H.J.W. de Baar, U.V. Bathman, K. Lochte and M.M. Rutgers Van der Loeff (1997). Ecology and biogeochemistry of the Antarctic Circumpolar Current during austral spring: a summary of Southern Ocean JGOFS cruise ANT X/6 of R.V. Polarstern. Deep-Sea Research II, 44, 1-21.

Takahashi, T. (1989). The carbon dioxide puzzle. Oceanus, 32, 22-29.

Takahashi, T., R.A. Feely, R.F. Weiss, R.H. Wanninkhof, D.W. Chipman, S.C. Sutherland and T.T. Takahashi (1997). Global air-sea flux of CO2: an estimate based on measurements of air-sea $\mathrm{pCO}_{2}$ difference. Proc. Natl. Acad. Sci. USA, 94, 8292-8299.

Takahashi, T., J. Olafsson, J.G. Goddard, D.W. Chipman and S.C. Sutherland (1993). Seasonal variations of $\mathrm{CO}_{2}$ and nutrients in the high-latitude surface oceans: a comparative study. Global Biogeochemical Cycles, 7, 843-878.

Tans P.P., Y.I. Fung and T. Takahashi (1990). Observational constraints on the global atmospheric $\mathrm{CO}_{2}$ budget. Science, 247, 1431-1438.

Treguer P. and G. Jacques (1992). Dynamics of nutrients and phytoplankton, and fluxes of carbon, nitrogen and silicon in the Antarctic Ocean. Polar Biology, 12, 149162.

Turner D., and N.J.P. Owens (1995). A biogeochemical study in the Bellingshausen Sea: overview of the STERNA 1992 expedition. Deep-Sea Research II, 42, 905932. 
UNESCO (1984). La escala de salinidades prácticas de 1978 y la ecuación de estado del agua de mar de 1980. Documentos técnicos de la Unesco sobre ciencias del mar, 36, 1-21.

UNESCO (1986). Progress on Oceanographic Tables and Standards 1983-1986. Work and recommendations of the UNESCO/SCOR/ICES/IAPSO Joint Panel. UNESCO Technical Papers in Marine Science, 50.

Varela M., E. Fernández, J. Sostres, P. Serret et al. Spatial and temporal variability of size-fractioned phytoplankton biomass, production and composition in the Antarctic Peninsula (FRUELA cruises). Deep-Sea Research II (submitted)

Wanninkhof, R. (1992). Relationship between wind speed and gas exchange over the ocean. Journal of Marine Research, 97, 7373-7382.

Watson A.J., C. Robinson, J.E. Robertson, P.J. LeB Williams and M.J.R. Fasham (1991). Spatial variability in the sink for atmospheric carbon dioxide in the North Atlantic. Nature, 350, 50-53.

Weiss, R. F. (1974). Carbon dioxide in water and seawater: the solubility of a non-ideal gas. Marine Chemistry, 2, 203-215.

Woolf, D. K. and S.A. Thorpe (1991). Bubbles and the air-sea exchange of gases in near-saturation conditions. Journal of Marine Research, 49, 435-466.

Yentsch, C. S. and D.W. Menzel (1983). A method for the determination of phytoplankton chlorophyll and phaeophytin by fluorescence. Deep-Sea Research, 10,221- 
a) Macro' $95 \& 96$

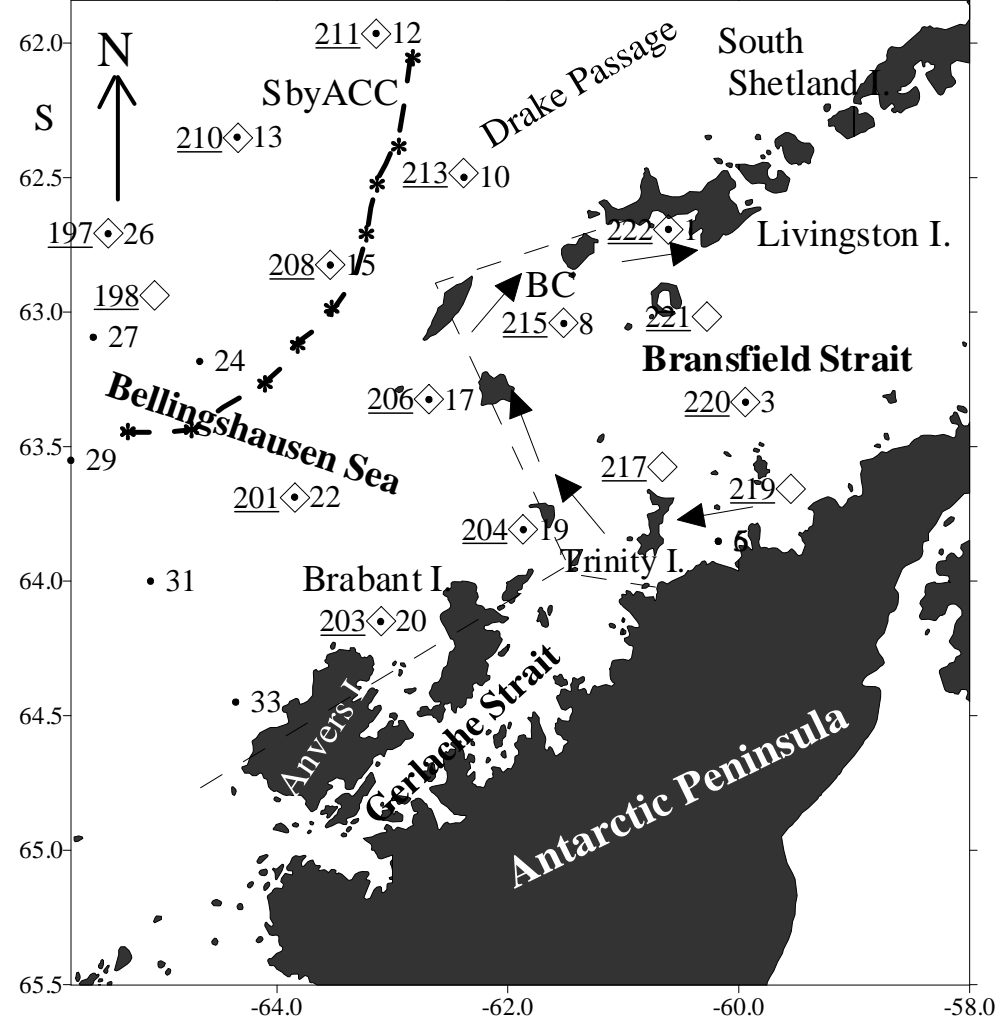

b) Meso' 95 \& 96
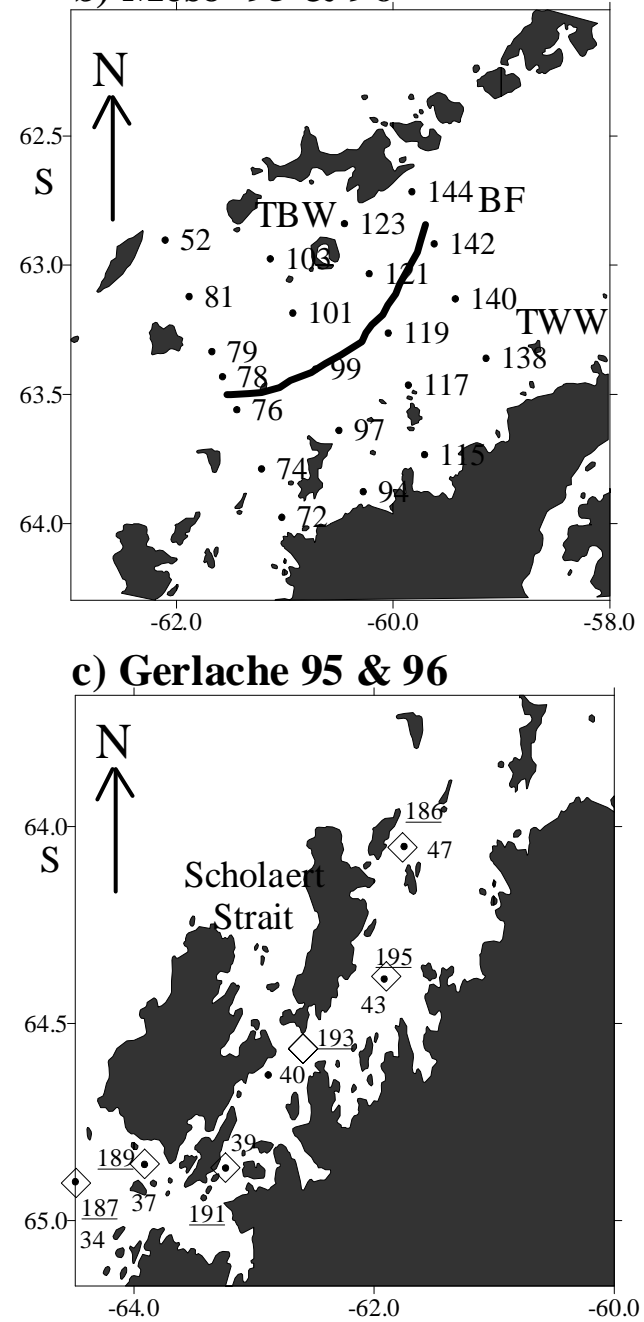

Figure 1 

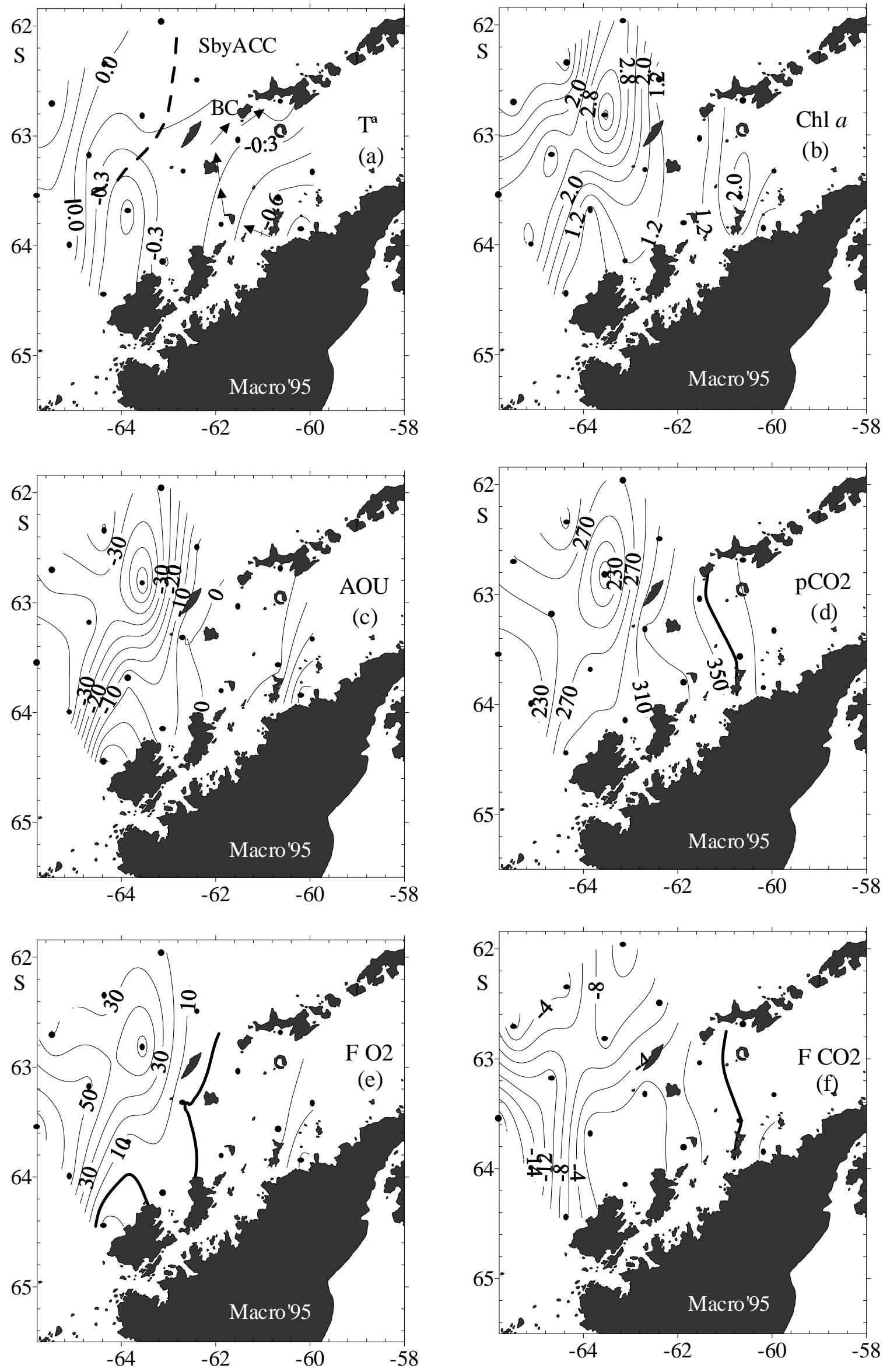

Figure 2 

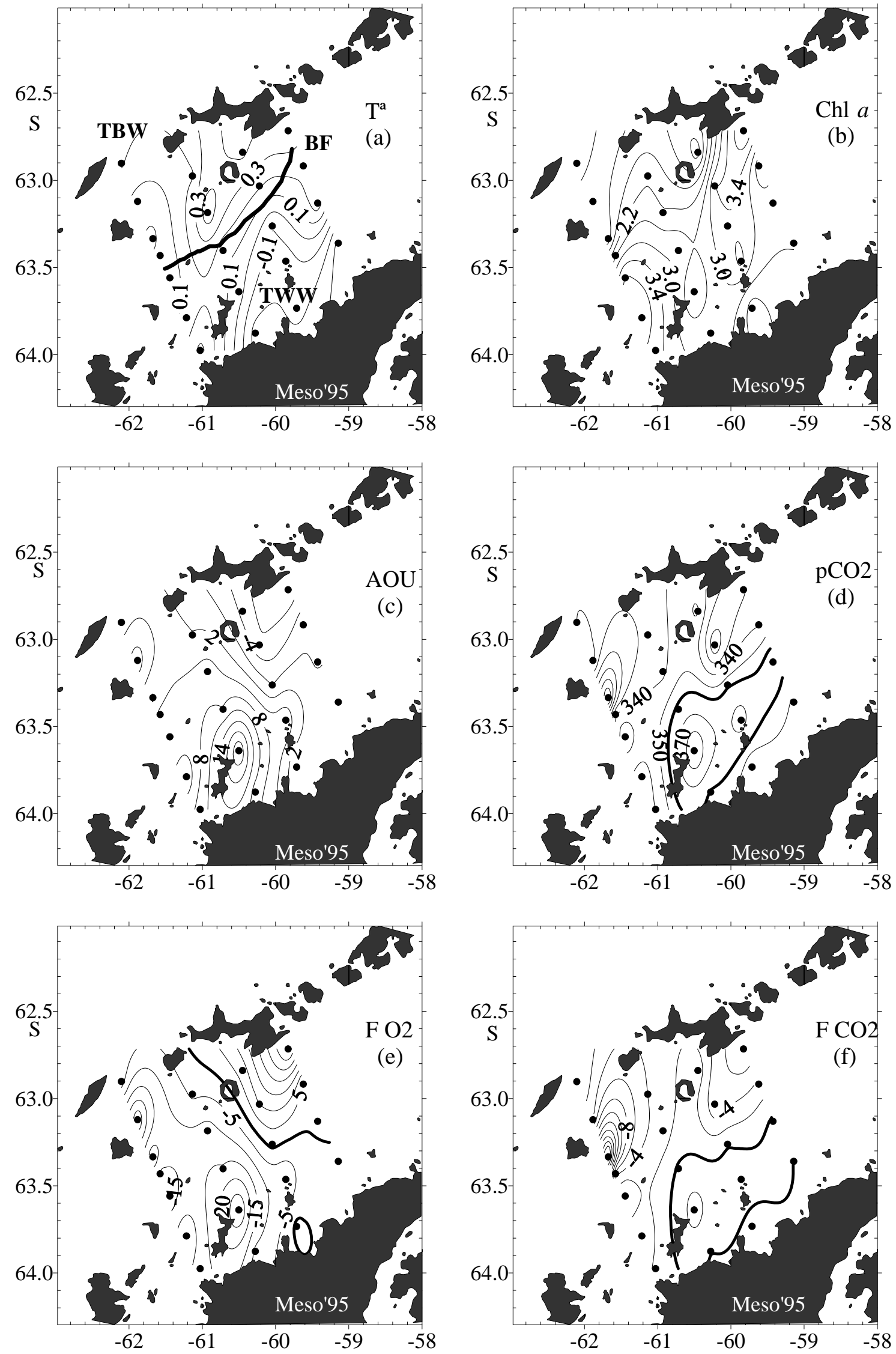

Figure 3

ALVAREZ ET AL 

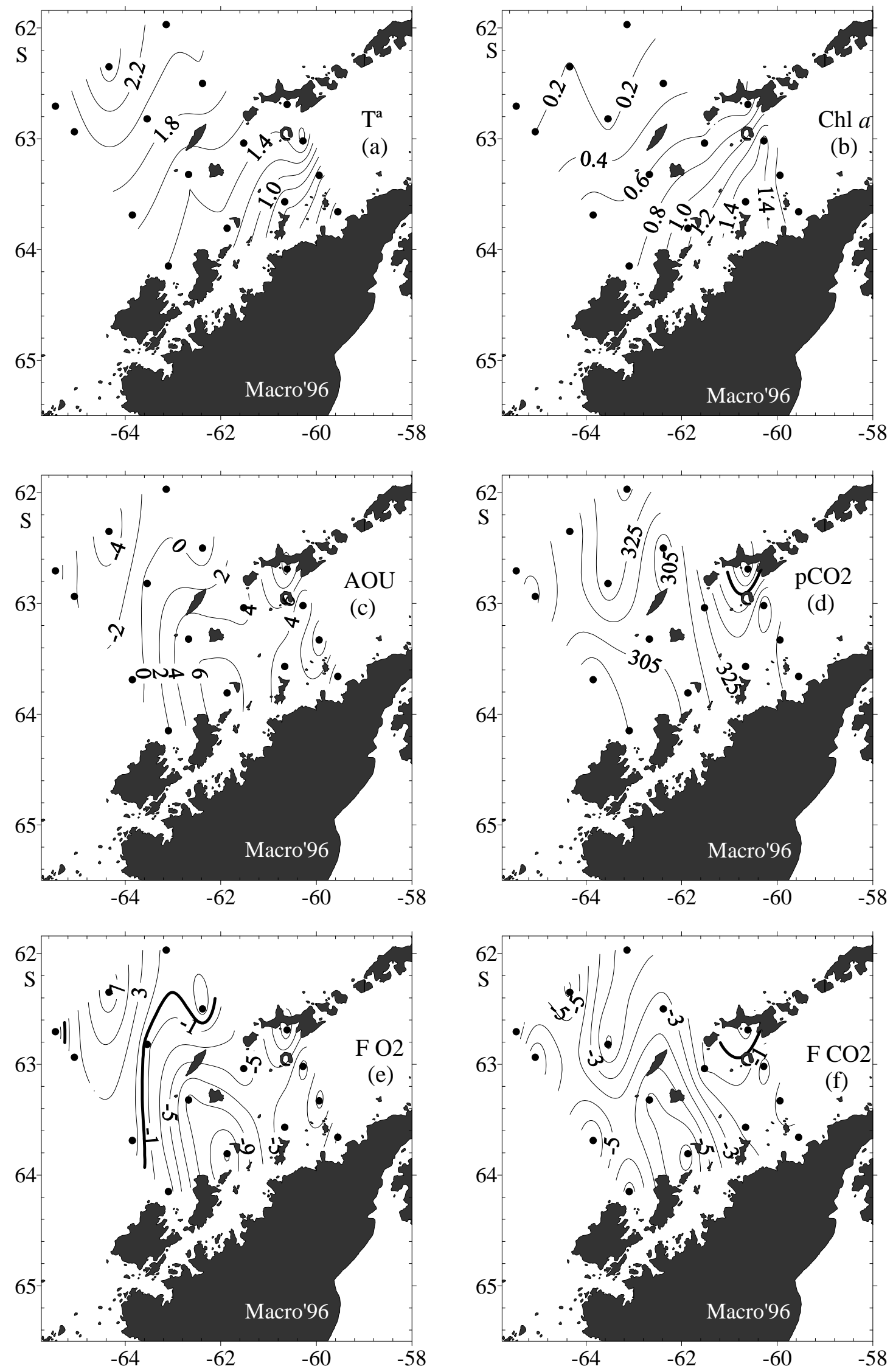

Figure 4

ALVAREZ ET AL 



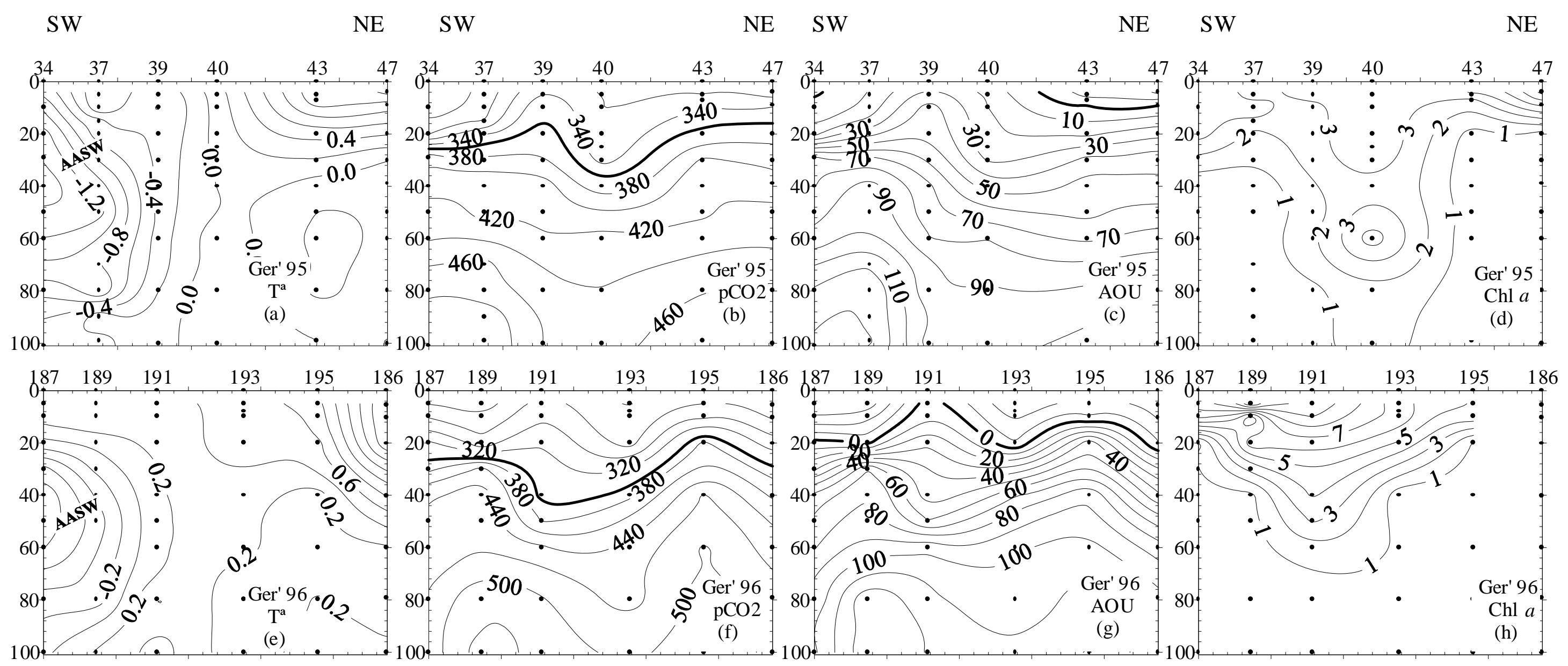

Figure 5

ALVAREZ ET AL 

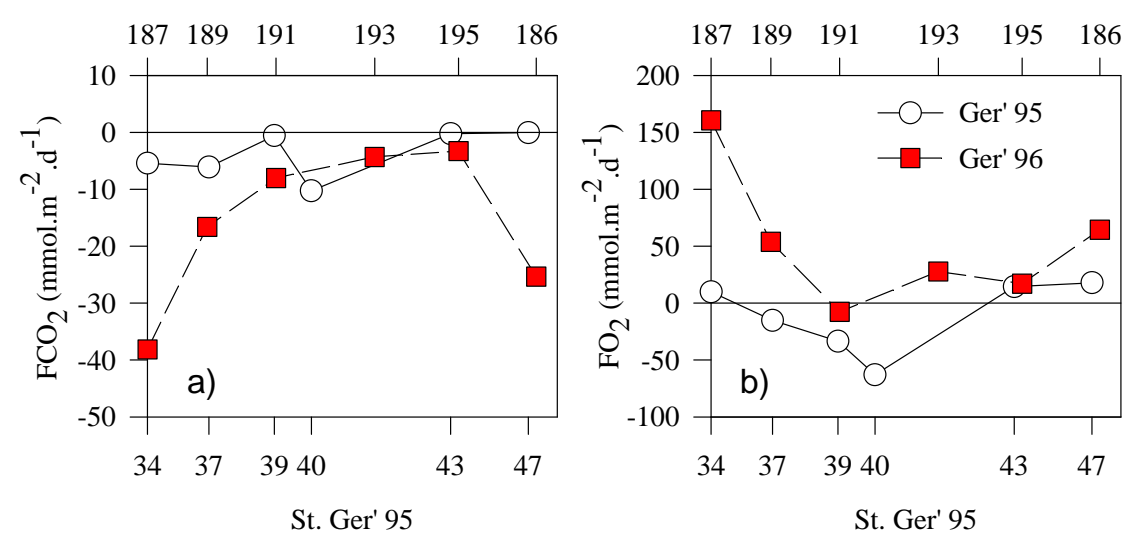

Figure 6

ALVAREZ ET AL 